\title{
AN EXPLORATION OF THE KNOWLEDGE HIGH SCHOOL GUIDANCE COUNSELORS IN MISSOURI HAVE AS THEY ASSIST UNDOCUMENTED STUDENTS TRYING TO GAIN ACCESS TO COLLEGE
}

A Dissertation
presented to
the Faculty of the Graduate School
at the University of Missouri-Columbia
In Partial Fulfillment
of the Requirements for the Degree
Doctor of Education
Dr. Carole Edmonds, Dissertation Supervisor
December 2014
barTHA DEVRIES


(C) Copyright by Martha DeVries 2014

All Rights Reserved 
The undersigned, appointed by the dean of the Graduate School, have examined the thesis or dissertation entitled

\section{AN EXPLORATION OF THE KNOWLEDGE HIGH SCHOOL GUIDANCE COUNSELORS IN MISSOURI HAVE AS THEY ASSIST UNDOCUMENTED STUDENTS TRYING TO GAIN ACCESS TO COLLEGE}

presented by Martha DeVries, a candidate for the degree of doctor of education, and hereby certify that, in their opinion, it is worthy of acceptance.

Professor Carole Edmonds

Professor Tim Wall

Professor Bill Hedge

Professor Shelly Hiatt 
...Thanks to Mike, Hannah, and Haley for living with me through years of courses, hours of writing, and millions of excuses. To mom, thank you for your help and encouragement. To daddy, I'm sorry you did not see this completed, but I know you would be proud. 


\section{ACKNOWLEDGEMENTS}

I would like to thank Dr. Philip Messner who guided me through several dissertation topics until I found one about which I could feel passionate. His patience and encouragement helped me to persevere even when I wanted to throw in the towel and admit failure. I owe and extreme debt to Dr. Carole Edmonds who took over as my adviser upon Dr. Messner's retirement. Her careful attention to every written word, her valuable feedback, and her insistence on regular progress motivated me to complete the project during a time in my personal life when motivation was in short supply. Her dedication to this project, her investment in me as a learner, and her interest in my topic have been a continuous source of inspiration. 


\section{TABLE OF CONTENTS}

ACKNOWLEDGEMENTS

LIST OF TABLES AND FIGURES viii

ABSTRACT $\quad$ ix

Chapter

1. INTRODUCTION 1

Background 1

High School Guidance Counselors 2

Roles of High School Guidance Counselors 3

High School Guidance Counselors and College Access 4

Undocumented Students

The High School Counselors Role 5

Laws Governing Primary and Secondary Education 6

Laws Governing Post-secondary Education 7

$\begin{array}{lr}\text { Theoretical Framework } & 8\end{array}$

Critical Race Theory 9

$\begin{array}{ll}\text { Latino Critical Theory } & 10\end{array}$

$\begin{array}{ll}\text { Social Capital Theory } & 11\end{array}$

Statement of the Problem 13

Purpose of the Study 14

Limitations, Assumptions, and Design Controls 15

Definition of Key Terms 16

$\begin{array}{ll}\text { Summary } & 18\end{array}$ 
Chapter

2. REVIEW OF RELATED LITERATURE

$\begin{array}{ll}\text { Introduction } & 20\end{array}$

$\begin{array}{ll}\text { Conceptual Underpinnings } & 22\end{array}$

Critical Race Theory $\quad 22$

Latino Critical Theory $\quad 25$

$\begin{array}{ll}\text { Social Capital Theory } & 27\end{array}$

An Intersection of Frameworks $\quad 29$

High School Guidance Counselors and College Access 31

The Law and Undocumented Students 33

The High School Guidance Counselor's Role 34

Laws for Primary and Secondary Education 37

Laws for Post Secondary Education 38

$\begin{array}{ll}\text { Summary } & 39\end{array}$

Chapter

3. RESEARCH DESIGN AND METHODOLOGY 41

Introduction 41

Problem and Purpose Overview $\quad 42$

Purpose of Study 43

Research Questions $\quad 43$

Population and Sample $\quad 44$

The Use of Case Study 45

Tools of Case Study $\quad 46$

Document Analysis $\quad 46$

$\begin{array}{ll}\text { Interviews } & 47\end{array}$ 
Focus Groups $\quad 48$

$\begin{array}{ll}\text { Observation } & 48\end{array}$

Data Analysis in Case Study 49

Document Analysis $\quad 49$

$\begin{array}{ll}\text { Interview Analysis } & 50\end{array}$

Focus Group Analysis $\quad 50$

Observation Analysis $\quad 51$

Theme Development 51

$\begin{array}{ll}\text { Summary } & 52\end{array}$

Chapter

4. PRESENTATION AND ANALYSIS OF DATA 53

Introduction $\quad 53$

Study Design $\quad 54$

Data Collection Methods $\quad 55$

Conceptual Underpinnings 56

$\begin{array}{ll}\text { Research Questions } & 57\end{array}$

Process of Data Analysis $\quad 58$

$\begin{array}{ll}\text { The Setting } & 61\end{array}$

$\begin{array}{ll}\text { Participants } & 63\end{array}$

$\begin{array}{ll}\text { Themes } & 63\end{array}$

Lack of Awareness $\quad 65$

$\begin{array}{ll}\text { Lack of Knowledge } & 70\end{array}$

Lack of Knowledge Concerning DREAM Act $\quad 70$

Lack of Knowledge Concerning Deferred Action

for Childhood Arrivals $\quad 72$ 


\section{Chapter}

5. SUMMARY, RECOMMENDATIONS, AND CONCLUSIONS 77

$\begin{array}{ll}\text { Introduction } & 77\end{array}$

$\begin{array}{ll}\text { Summary of Findings } & 79\end{array}$

$\begin{array}{ll}\text { Lack of Awareness } & 80\end{array}$

Lack of Knowledge $\quad 82$

$\begin{array}{ll}\text { Lack of Training } & 84\end{array}$

$\begin{array}{ll}\text { Conclusions } & 86\end{array}$

$\begin{array}{ll}\text { Limitations } & 87\end{array}$

$\begin{array}{ll}\text { Implications for Practice } & 89\end{array}$

$\begin{array}{ll}\text { Concluding Overview } & 91\end{array}$

$\begin{array}{ll}\text { REFERENCES } & 94\end{array}$

$\begin{array}{ll}\text { Appendix A } & 97\end{array}$

Informed Consent

District-Level Permission for Counselor

$\begin{array}{lr}\text { Participation Letter } & 98\end{array}$

Administrative Permission for Counselor

Participation 99

Letter of Informed Consent 100

Informed Consent Form 102

$\begin{array}{ll}\text { Appendix B } & 103\end{array}$

Protocol and Procedures 
Interview Protocol 104

Interview Questions 105

Focus Group Protocol 106

Focus Group Questions 107

$\begin{array}{ll}\text { Appendix C } & 108\end{array}$

$\begin{array}{ll}\text { VITA } & 109\end{array}$ 


\section{LIST OF FIGURES}

Figure 1: The Process of Data Analysis $\quad 61$

Figure 2: Participants 63

Figure 3: The Infinite Circle of Gaps 87 


\title{
AN EXPLORATION OF THE KNOWLEDGE HIGH SCHOOL GUIDANCE COUNSELORS IN MISSOURI HAVE AS THEY ASSIST UNDOCUMENTED STUDENTS TRYING TO GAIN ACCESS TO COLLEGE \\ Martha DeVries \\ Dr. Carole Edmonds, Dissertation Supervisor
}

\begin{abstract}
The purpose of this qualitative study was to explore the knowledge high school guidance counselors in Missouri have as they work with undocumented students who are trying to gain access to college. Utilizing the tools of case study including document analysis, focus groups, interviews, and observations, this study attempts to gain a thorough understanding about what high school guidance counselors in Missouri know and what they do not know about assisting undocumented students seeking access to college and other post-secondary opportunities. The participants in this study were high school guidance counselors in a mid-sized urban/suburban school district. Because Missouri is not a DREAM act state, these high school guidance counselors face barriers when assisting undocumented students. The study indicates high school guidance counselors in Missouri lack awareness about undocumented students, lack knowledge about laws, practices, and programs concerning undocumented students, and need training about how to best serve undocumented students who are applying for post-secondary educational opportunities.
\end{abstract}




\section{CHAPTER 1}

\section{INTRODUCTION TO THE STUDY}

\section{Background}

At 18 years old, Maria entered her senior year of high school excited about what the future held for her. She secured a spot on the golf team; she was finishing her course work in her high school's highly competitive and rigorous International Baccalaureate Diploma Program; and was planning to join her schools DECA club to learn more about the business world. She had the typical senior year jitters about the finality of childhood and the beginnings of adulthood, but her fears about college were different from many of her peers. As a third grader, Maria came to the Midwest when her parents left Mexico and entered the United States without proper immigration documentation. Her father had gotten work as a landscaper and her mother had stayed home to raise the children.

Their life was modest, but they had a safe, comfortable home, enough money to pay for their living expenses, and Maria and her siblings were attending quality public schools and doing very well. Within just a few years, Maria no longer needed English Language Learner (ELL) services. In spite of a few minor heath issues, she was an excellent student who always worked hard in every subject.

Entering her senior year, however, Maria was extremely worried about college. Of course she had the typical concerns: Are my test scores high enough? Will I get into a good college? Will I get enough scholarship money? In addition to those worries, however, Maria had others: Will I disclose my family’s immigration status by applying for college? How will I pay for college if I am not eligible for federal financial aid? What if I cannot go to college and have to 
get a low-paying job? How will I explain to teachers, friends, and my guidance counselor why I am not going to attend college after high school? (Scroggs, Julie personal communication, February 4, 2013).

Unfortunately, Maria's story is repeated over and over, year after year, in high schools in every state in the United States. It is estimated that 1.6 million undocumented school children are attending public schools. Researchers estimate between 50,000 and 60,000 of those children graduate from a U.S. high school each year (Gildersleeve \& Ranero, 2010). Undocumented students struggle with disadvantages compared to their native peers in terms of employment, social services, and basic human rights. Additionally, because of limited economic and social resources, they also struggle to access higher education (Gildersleeve, Rumann, \& Mondragon, 2010).

\section{High School Guidance Counselors}

In the United States, high school students navigate the college application process utilizing a variety of tools including private college counselors, the internet, family members, college admissions counselors, and high school guidance counselors. According to the National Association for College Admission Counseling (2010), secondary school guidance counselors rate planning and preparing for postsecondary options as one of their two most important priorities. Yet they only spend a quarter of their time doing such work (School Counselors Contribute to College Access and Success, 2013). Additionally, the American School Counselor Association (ASCA) outlines in their School Counselor Competencies an entire section on Individual Student Planning. While this planning is not strictly intended for the purpose of college-going after high school, it is a major component. Competent high school guidance 
counselors help "students learn the importance of college and other post-secondary education and help students navigate the college admissions process" (American School Counselor Association, 2013).

\section{Roles of High School Guidance Counselors}

The evolution of the role high school guidance counselors play in the college-going process has been affected by multiple forces. With the dominance of other job roles including psychological development, testing, administrative support, and therapeutic work with students, college planning and preparation was not originally seen as a priority for high school guidance counselors (McDonough, 2005). Additionally, during the early 1980s and 1990s, guidance counselors themselves advocated for their role within schools to be more focused on the mental health of their students rather than on selling college to a few, elite students (Carroll, 1985; McDonough, 2005). Additionally, guidance counselors have, at times, been criticized for serving as gatekeepers in the college-going process. By advising based on personal assessments of the students' character, maturity, and appearance, counselors guided one type of student toward a college preparatory high school curriculum while encouraging working-class students to select a traditionally vocational track. Thus making it difficult for certain types of students to be admitted and find academic success on a college campus (McDonough, 2005).

Today's high school guidance counselor, however, works under a very different set of expectations when it comes to career counseling and college advising. Nation-wide there is an expectation that high schools are preparing graduates for success in the world of work. As such, high school guidance counselors are spending much more of their time helping students with career exploration and educational guidance in order to reach those career goals (American 
School Counselor Association, 2013). Unfortunately, one factor continues to impede high school guidance counselors as they attempt to focus on college advising and that is training. Few preservice counselor education programs provide training on college access, cost, or financial aid. Additionally, while many counselors have the opportunity for professional development throughout their career, until recently, college access and readiness has not been a professional development priority (McDonough, 2005). Recent efforts by the College Board and other organizations have brought attention to the need for increased training for high school counselors working with students with college aspirations and aptitudes, but districts and schools tend to funnel professional development funds toward classroom teachers in an effort to increase student performance rather than toward counseling departments (College Board, 2013).

\section{High School Guidance Counselors and College Access}

Research reveals high school counselors can make a positive impact on students' aspirations, achievements and financial aid knowledge. In order to have that impact, however, high school guidance counselors must be able to provide direct services to students and their families both frequently and regularly (McDonough, 2005). Large case-loads and other demands of the job often make college advising difficult for high school counselors; however, with increased focus on college-and career- readiness in order to prepare a well-trained workforce, the demand for such work is on the increase. The American School Counselor Association (ASCA) recommends that school counselors spend up to 70 percent of their time providing direct services to students, which could include college advising, yet gathering accurate data on how much time counselors actually spend doing college advising is extremely difficult and seems nearly impossible to measure. According to a study by the National Center for Educational Statistics, only 43 percent of guidance counselors at public high schools spent 20 percent or more of their 
time on college counseling. Consider converse of the statistic. Fifty-seven percent of guidance counselors in public high schools spent 0-19 percent of their time doing college advising (U.S. Department of Education, 2004).

\section{Undocumented Students}

As alluded to earlier, while searching for, applying to, and navigating financial aid is an important part of college advising, it is not the only critical role high school guidance counselors play in this college-going process. The pathway to college really begins in pre-school; skills built in elementary school and middle school are critical to college-readiness. High school guidance counselors, however, play a critical role as they help students select courses and progress toward their aspirations (McDonough, 2005). According to Martinez and Klopott (2003), in order to best assist minority, low-income, and first generation college students in the college-going process, a complete reinvention of current middle and high school systems may be required. High school guidance counselors will play a significant role in assuring these students are well prepared, have access to information about college early in their high school experience, and enroll in high school courses that will provide adequate preparation for college-level work. Students who are in the United States without proper legal documentation are often a sub-group within this larger group of minority, low-income, and first generation college students. As such, high school guidance counselors are increasingly essential in helping undocumented students navigate high school in order to be college ready.

The High School Counselor's Role

Undocumented students have college advising needs quite similar to minority, first generation, and low-income students. Often they have an underdeveloped sense of their post- 
secondary options, and recognize the need for a good job, but cannot always define what that means; nor can they always imagine an accurate route for earning the credentials in order to secure that good job. Additionally, parents of undocumented students recognize the importance of college, but need guidance from the school in order to understand the processes (Arriola \& Murphy, 2010).

Thus undocumented students are likely to need the services of their high school guidance counselor to navigate this process since private college counselors charge exuberant fees, making their services out of reach to the majority of undocumented students. Additionally, undocumented students often lack "cultural capital" which includes "knowledge, skills, education, and other advantages a person has that make the educational system a comfortable, familiar environment” (Gildersleeve, Rumann, \& Mondragon, 2010). Because of this, undocumented students rely on the people in their schools who have expertise in the navigation process of college-going.

\section{Laws Governing Elementary and Secondary Education}

According to the Fourteenth Amendment to the Constitution of the United States of America, people who are in the United States without documentation do have legal rights including the right to emergency health care; emergency shelter; disaster aid; due process related to unlawful search and seizure, arrest, and work related discrimination and unfair labor practices; and unfair housing discrimination (Gildersleeve, Rumann, \& Mondragon, 2010). Additionally, there are no laws in place to restrict undocumented immigrants from opening bank accounts, taking out private loans, or purchasing private health insurance (Gildersleeve, Rumann, \& Mondragon, 2010). In 1982, the Supreme Court confirmed the children of undocumented 
immigrants have the right to seek a public K-12 education in its landmark decision Plyler v. Doe. The court, however, did not address issue of matriculation to institutions of higher education (Gildersleeve, Rumann, \& Mondragon, 2010; Drachman, 2006). The two sides of this on-going debate were solidified in the Plyler v. Doe case. The Majority opinion concluded denying access to a free public education created an entire class of people who would be disabled because of their illiteracy, while the dissenting opinion argued since undocumented students are not in the United States legally, then the government has no responsibility to provide government services (Drachman, 2006). These two opposing opinions continue to divide ideologies on the subject of educating undocumented students at the post-secondary level.

\section{Laws Governing Post-Secondary Education}

There are several laws concerned with and continue to spark debate regarding undocumented students and their ability to access higher education. The two most important federal laws are Illegal Immigration Reform and Immigrant Responsibility Act of 1996 (IRIRA) and the Personal Responsibility and Work Opportunity Reconciliation Act of 1996 (PRWORA). What is clear about these two laws is that undocumented students seeking higher education do not have access to federal financial aid. What, however is unclear, is whether or not states have the right to allow undocumented students to attend public universities and pay in-state resident tuition rates (Gildersleeve, Rumann, \& Mondragon, 2010; Drachman, 2006). According to Gildersleeve, Rumann, and Mondragon (2010), “Although no federal legislation prevents undocumented students from attending higher education, some states and individual institutions have taken action to contest or deny undocumented admissions." Furthermore, "there is no uniform set of standards for undocumented students' admission and access to higher education across the board, and rules and regulations vary considerably by state" (p. 10). 
The Development, Relief, and Education for Alien Minors (DREAM) Act was first introduced in 2001. Its original purpose was to clarify offering in-state resident tuition to undocumented students and provide a pathway for citizenship. The current version of the DREAM Act would follow a two-step process toward legal residency. First, young people would have a conditional status for six to eight years while either pursuing higher education or serving in a branch of the U.S. military. Then, after two years of college or military service, they could apply for permanent residency. Other conditions must also be met in order for students to meet the requirements outlined in the DREAM Act. Students must have entered the country before they turned 16 years old; they must have lived in the United States for at least five years; they must have been admitted to a post-secondary institution; they must have earned a high school diploma or General Education Diploma (GED); and they must have "good moral character" (Gildersleeve, Rumann, \& Mondragon, 2010).

\section{Theoretical Frameworks}

The theoretical frameworks for this study are based on theories rooted in social justice issues. Because many undocumented students are non-white it is appropriate to consider Critical Race Theory as a lens through which to analyze access, or lack thereof, to college for undocumented students. Closely related to Critical Race Theory is Latino Critical Theory. Since much of today's immigration debate surrounds Latinos/as entering through the southern border of the United States and the discrimination these immigrants face, considering the quest of undocumented students through this, more precise lens is also appropriate. A final theoretical framework to consider is Social Capital Theory which focuses on the privileges a person has because advantageous relationships and how that privilege can affect college access. 


\section{Critical Race Theory}

Much of the criticism about how undocumented students are currently treated in the college-going process is addressed through Critical Race Theory (CRT) which is the study of the relationship among race, racism, and power. It includes consideration of economic issues, historical context, group-interest, self-interest, feelings, and the unconscious. Those who use CRT as way of looking at social situations do so in order to gain understanding a better understanding of the issue as well as to transform society for the better (Delgado \& Stefancic, 2001).

While the existence of white undocumented students in the United States is possible, the vast majority of them are non-white. Because of this, CRT is an appropriate lens through which to consider their plight. One primary tenant of CRT is that racism is ordinary, that is, it is the way society does business and is the common experience of most people of color in this country. This is one of the factors that makes racism so difficult to address, let alone cure, because as a society, there is a tendency to overlook the everyday acts of racism while only considering the most blatant acts of racism as appalling. Additionally, there is little incentive to eradicate racism and racist practices within society because racism advances the interests of both whites and the working middle class. Therefore, even though races are nothing more than categories invented and manipulated by society, the impact of racism is evident throughout society, including both in secondary and post-secondary learning institutions (Delgado \& Stefancic, 2001). Further complicating the issue is the fact that few people have a single identity. Everyone has potentially conflicting, overlapping identities, loyalties, and allegiances (Perez, Cortes, Ramos, \& Coronado, 2010). And this is the situation in which many undocumented students find themselves. 
Critical Race Theory also challenges the concepts of meritocracy and colorblindness. Perez Huber posits districts, schools, and faculty members, in trying to be politically correct and fair, claim to have policies that reward students on merit and with colorblindness by claiming to have a neutral system that functions for all students in the same way. By learning from the educational experiences from communities of color, however, oppressive structures and practices have been revealed. Through this revelation of racism in education, social and racial justice efforts can increase empowerment among communities of color (2010). While many non-white students face innumerable disadvantages in the college access game compared to their white peers, the disadvantages are even more pronounced in non-white students who do not have legal immigration status in the United States.

\section{Latino Critical Theory}

An off-shoot of Critical Race Theory, Latino Critical Theory or, LatCrit, was initially developed as a way of considering the subordination of ethnic groups through public policy and education, because scholars believed Critical Race Theory focused too much on the oppression of the black community within the social constructs of a Black-White society (Trucios-Haynes, 2001) while ignoring the challenges faced by other ethnic groups - Latinos and Latinas in particular (Delgado Bernal, 2002). Additionally LatCrit considers the intersection racism and nativism. Perez Huber defines racism as the "the assigning of values to real or imagined differences in order to justify white supremacy, to the benefit of whites and at the expense of People of Color, and thereby defend the right of whites to dominance" (2010, p. 80). Additionally, nativism includes these critical components: opposition to the foreigner, protection of a nationalistic identity, and the foreigner becomes a perceived threat to the nationalistic identity (Perez Huber, 2010). When originally conceptualized, nativism specifically favored those 
of Anglo-Saxon descent and disparaged many groups of "white" immigrants as well as immigrants of color. Thus, Perez Huber defines nativism as "the practice of assigning values to real or imagined differences, in order to justify the superiority of the native, and to defend the native's right to dominance, at the expense of the non-native" (2010, p. 80). Finally, Perez Huber combines these concepts to racist nativism defined as "the assigning of values to real or imagined differences in order to justify the superiority of the native, who is perceived to be white, over the non-native, who is perceived to be People and Immigrants of Color, and thereby defend the native's right to dominance" (2010, p. 81$)$.

Perez Huber argues that evidence of racist nativism is evident throughout the history of the United States. Some obvious examples include the 1882 Chinese Exclusion Act as well as Mexican repatriation programs that were instituted in the 1930s and the Japanese Internment camps during World War II (2010). Racist Nativism, however, is not a thing of the nation's past. Its presence can be seen as undocumented students, most of whom are non-white, and all of whom are non-native, attempt to navigate college access.

\section{Social Capital Theory}

Racism has emerged as one of the key social problems in the United States (Yosso, 2005). While the impact of racism has grown more subtle over the last century, a need remains to develop "necessary tools to effectively analyze and challenge the impact of race and racism in US society" (p. 70). Yet race alone cannot account for the struggles often faced by undocumented students as they attempt to access post-secondary educational opportunities. Social Capital offers another lens through which to consider their plight. One of the tenants of Social Capital Theory is that having knowledge and understanding about the upper and middle 
class is considered a valuable asset, even capital, in a society with a hierarchal structure. As such, scholars have attributed success, including academic success, to either being born into a family who has the knowledge that is considered valuable or to gain the knowledge that is considered valuable in order to achieve social and educational mobility (Bourdieu \& Passeron, 1977). Educational practitioners and theorists have often used this theoretical framework to explain why academic and social outcomes are often lower for students of color, which would often include undocumented students, than white students. Thus the assumption has traditionally been that students of color lack the social and cultural capital which makes social mobility possible. By doing this, educational institutions ignore the cultural wealth that students of color and undocumented students possess (Yosso, 2005).

In general social capital is understood as networks of people and community resources. These networks provide both instrumental support and emotional support as individuals navigate society's institutions, including secondary and post-secondary educational institutions. By having some connection, either directly or indirectly, with people who know how to navigate various systems, a person is more likely to find success throughout the navigation process (Coleman, 1988). Yosso posits students of color posses five other strands of cultural wealth besides simply Social Capital. These other forms of capital are identified as (a) aspirational capital, that is the ability to maintain hopes and dreams for the future even in the face of real and perceived barriers, (b) linguistic capital, that is the ability to communicate in more than one language and or style, (c) familial capital, that is the cultural knowledge cultivates a sense of community history, memory, and cultural intuition, (d) navigational capital, that is the skills required to navigate through social institutions, particularly those designed to be served by the dominant society, and (e) resistant capital, that is the skills fostered through oppositional 
behavior and challenging oppression (2005). It is at this intersection where high school guidance counselors must work when helping undocumented students gain access to college and other post-secondary opportunities. There must be an understanding of the value of social capital throughout the entire process, yet at the same time there must be a recognition of the cultural wealth undocumented students posses (Yosso, 2005). High school counselors must be guides to help undocumented students access social capital as they work with students on applications for admissions, scholarships, and financial aid; they must connect students with community members who have clout with institutions and organizations; they must help students become proficient in both written and spoken formal language. Additionally, all educators, including high school guidance counselors, are under ethical oblication to help undocumented students present themselves as person who can bring something special to campus by highlighting their cultural wealth which includes a background as an immigrant, a poly-lingual speaker and writer, and an individual with a rich cultural heritage.

\section{Statement of the Problem}

Although undocumented students graduate from high schools in the United States every year (Gildersleeve \& Ranero, 2010), many are not going on to seek post-secondary educational opportunities at colleges and universities. Attending college, earning a degree, and finding a career can provide hope for undocumented students in that "company sponsorships [may be] the only realistic opportunity of achieving legal status in the United States" (Ortiz \& Hinojosa, 2010, p. 54). Navigating the college admission process is a daunting task for any student, but especially for a student who is in the United States without proper and legal paperwork. While navigating college admissions often takes priority early in the process, undocumented students face more issues when it comes to financing their education. Undocumented students are not allowed to use 
federal dollars (PELL grants and subsidized loans) to pay for post-secondary educational expenses and in most states, undocumented students must pay non-resident tuition rates (out-ofstate), these students are often driven away from some of the most affordable educational opportunities available which include community colleges, regional, and state institutions. While private colleges and universities generally do not have resident and non-resident tuition rates (College Board, 2013) and are allowed to offer scholarships to undocumented students, their cost of attendance and the lack of federal aid often makes a private college or university just as out of reach as a state supported one.

High school guidance counselors who are frequently and consistently available to provide direct services to students and their families concerning college readiness and admissions have a great impact on aspirations, achievement, college enrollment, and financial aid knowledge. This is especially true in schools that serve minority, low-income, and first generation college students (McDonough, 2005). Most undocumented students fit into one, if not all, of these categories. Furthermore, high school guidance counselors have an ethical obligation to serve all students without regard to race, ethnicity, socio-economic status, or immigration status (American School Counselor Association, 2013). Currently, there is a lack of information about the knowledge high school guidance counselors have in Missouri as they assist undocumented students trying to gain access to college. It is essential, then, to understand what high school guidance counselors know and what high school guidance counselors do not know about assisting undocumented students attempting to gain access to college. With this knowledge, training can be implemented and undocumented students can receive appropriate services from their high school guidance counselors. 


\section{Purpose of the Study}

The purpose of the study is to explore the knowledge of high school guidance counselors in Missouri have when assisting undocumented students attempting to gain access to college. High school guidance counselors play a pivotal role in the college-going process for many public high school students (School Counselors Contribute to College Access and Success, 2013) and the number of undocumented students who are graduating from high schools in the United States continues to rise (Gildersleeve, Rumann, \& Mondragon, 2010). Therefore, gaining an understanding about Missouri's high school guidance counselors and their knowledge concerning college access for undocumented students is essential in understanding how best to educate guidance counselors.

Throughout this study the research question is: What is the knowledge high school guidance counselors in Missouri have to assist undocumented students attempting to gain access to college? A secondary research question thus emerges. Once the knowledge high school guidance counselors have concerning college access for undocumented students is identified, then the question of identifying deficits in the knowledge emerges. Therefore, the secondary research question is: What knowledge do high school guidance counselors in Missouri lack to assist undocumented students attempting to gain access to college.

\section{Limitations, Assumptions, and Design Controls}

The first limitation to this study was geographic. High school guidance counselors working in a city in the northwestern corner of Missouri were the only counselors who participated in interviews, focus groups, and observations. Missouri is not one of the eleven states that has adopted a version of the DREAM Act. If high school counselors from a DREAM 
Act state would have been included in the study, the results might have been different. Another limitation of the study was a lack of awareness of the problem. Public high schools do not require students to prove their immigration status; therefore high school guidance counselors must depend on students to self-disclose their undocumented status. If students are nervous about the possibility of their family's arrest or deportation, they are less likely to disclose their undocumented status to someone at school. As such, high school guidance counselors may have worked with undocumented students without realizing it.

An assumption of the research project was most high school guidance counselors have had experience working with undocumented students. This assumption could have caused counselors to disclose information as "what I would do" rather than "what I did." Furthermore, since Missouri boarders a state that does have a version of the DREAM Act in place, high school counselors could live in a state with very different rules for undocumented students from the one in which they work.

\section{Definition of Key Terms}

Throughout this research project there are key terms readers should understand according to these specific definitions.

Critical Race Theory. Critical Race Theory (CRT) is the study of the relationship among race, racism, and power. It includes aspects of economics, historical context, group-interest, selfinterest, feelings, and the unconscious. CRT scholars embrace an activist dimension. They not only want to understand the social situation, but to transform society for the better (Delgado \& Stefancic, 2001). 
DREAM Act. The Developmental and Education for Alien Minors Act is an unratified Constitutional amendment that would grant conditional permanent resident status for six years to undocumented students who arrived in the United States before they turned 16 years old. Some additional provisions of the law include requirements for good moral character, no criminal record, continual residence in the United States for at least five years, and graduation from a U.S. high school. An additional affect of the amendment would be resident tuition for undocumented students at public post-secondary institutions. At this point the DREAM Act has not been ratified therefore, it is not the law of the nation. Twelve states have passed some version of the DREAM Act: California, Illinois, Kansas, Maryland, Massachusetts, Nebraska, New Mexico, New York, Texas, Utah, Washington, and Wisconsin (Drachman, 2006).

In-state Resident Tuition. In-state tuition is the rate public colleges and universities charge state residents to attend the institution (College Board, 2013).

Latino Critical Theory. A branch of Critical Race Theory that considers issues of concern to Latinos/as such as immigration, language rights, and multi-identity (Delgado \& Stefancic, 2001).

Legal permanent resident. A legal permanent resident is a person who has been defined by immigration law as a person who can live and work lawfully within the United States (Monger \& Yankay, 2014).

Non-resident tuition. Non-resident tuition is the rate public colleges and universities charge non-resident students to attend the institution (also referred to as out-of-state tuition) (College Board, 2013). 
Social Capital. An aspect of human capital wherein social networks are given value such that individuals benefit from their social relationships (Coleman, 1988).

Social Capital Theory. The study of how relationships with members from a higher social class can influence the upward mobility of members of a lower social class. Social Capital Theory most often considers how those relationships affect the workplace, education, and other social institutions (Coleman, 1988).

State Residency. State residency is defined as the state in which a student makes his or her permanent home. Individual states define the requirements to meet state residency (College Board, 2013).

Undocumented Student. An undocumented student is a student living in the United States without legal permission and proper paperwork (Flores, 2010).

\section{Summary}

As stated earlier the purpose of this research study is to explore the knowledge of high school guidance counselors in Missouri as they assist undocumented students attempting to gain access to college. This chapter was divided into seven sections covering the following topics: (a) introduction to the study, (b) the background of the study, (c) theoretical frameworks for the study, (d) the statement of the problem, (e) the purpose of the study, which included two research questions, (f) limitations and assumptions of the study, and (g) definitions of key terms.

Chapter Two will provide a review of the literature associated with high school guidance counselors and their role in college admissions, the plight of undocumented students seeking to obtain access to colleges and universities, and an overview of the DREAM Act and the affect its 
implementation, or lack of implementation, is having on college admission and attendance rates of undocumented students. Additionally there will be a review of literature concerning qualitative research and Critical Race Theory, Latino Critical Theory, and Social Capital Theory. Chapter three will provide the methodology used in the study and will include research questions, information about the population and sample, and data collection and analysis. Chapter Four will provide an overview of the data and an analysis of the data. Finally Chapter Five will report findings, conclusions, and implications of the study. 


\title{
CHAPTER 2
}

\section{REVIEW OF RELATED LITERATURE}

\author{
Introduction
}

Between 50,000 and 65,000 undocumented students graduate from high schools in the United States every year (Gildersleeve \& Ranero, 2010). Many of them were primarily, if not exclusively, educated in American public schools. Yet an overwhelming majority of them are not going on to seek post-secondary educational opportunities at colleges and universities. Attending college, earning a degree, and finding a career can provide hope for undocumented students in that "company sponsorships [may be] the only realistic opportunity of achieving legal status in the United States" (Ortiz \& Hinojosa, 2010, p. 54). Navigating the college admission process is a daunting task for any student, but especially for a student who is in the United States without proper and legal paperwork. While navigating college admissions often takes priority early in the process, undocumented students face more issues when it comes to financing their education. Undocumented students are not allowed to use federal dollars (PELL grants and subsidized loans) or state dollars to pay for post-secondary educational expenses and in most states (Gonzales, 2010), most undocumented students must pay non-resident (out-of-state) tuition rates (Arriola \& Murphy, 2010), therefore, undocumented students are often driven away from some of the most affordable educational opportunities available which include community colleges, regional, and state institutions (Perez, 2010).

High school guidance counselors who are frequently and consistently available to provide direct services to students and their families concerning college-readiness and admissions have a great impact on aspirations, achievement, college enrollment, and financial aid knowledge 
(McDonough, 2005). This is especially true in schools that serve minority, low-income, and first generation college students. Most undocumented students fit into one, if not all of these categories. Furthermore, high school guidance counselors have an ethical obligation to serve all students without regard to race, ethnicity, socio-economic status, or immigration status (American School Counselor Association, 2013).

The purpose of the study is to explore the knowledge of high school guidance counselors in Missouri as they assist undocumented students attempting to gain access to college. High school guidance counselors play a pivotal role in the college-going process for many public high school students (School Counselors Contribute to College Access and Success, 2013) and the number of undocumented students who are graduating from high schools in the United States continues to rise (Gildersleeve, Rumann, \& Mondragon, 2010). Therefore, gaining an understanding about guidance counselors and their knowledge and their knowledge gaps concerning college access for undocumented students is essential in understanding how best to educate guidance counselors.

The literature review focuses first on the theoretical frameworks of Critical Race Theory (CRT), Latino critical theory (LatCrit), and Social Capital Theory. These three conceptual frameworks were frequently cited in the literature concerning college access for undocumented students, especially since inhibiting college access becomes a matter of social justice - or rather injustice. The next section of the literature review focuses on the role of the high school guidance counselor in helping students gain access to post-secondary educational opportunities. This includes both a discussion about the history and role of high school guidance counselors, and how that role has evolved to include college- and career- preparation and readiness. The next 
section of the literature review focuses on the current laws in place that govern access to postsecondary institutions for undocumented students.

\section{Conceptual Underpinnings}

When considering the plight of undocumented students attempting to gain access to college, three main theoretical frameworks offer lenses through which the problem can be viewed: Critical Race Theory, Latino Critical Theory, and Social Capital Theory. Since most undocumented students are people of color, utilizing Critical Race Theory as a lens allows consideration from a non-white point of view. Latino Critical Theory provides a lens to consider the problem from a Latino and Latina point of view. Considering many undocumented students came to the United States from Central or South American countries, and these immigrants are often the focus of attention around current immigration debates, this is an appropriate framework. Finally, Social Capital Theory can be linked to both of these frameworks when considering how relationships within and among cultural groups can advance social and educational mobility.

\section{Critical Race Theory}

Much of the criticism about how undocumented students are currently treated in the college-going process is addressed through Critical Race Theory (CRT) which is the study of the relationship among race, racism, and power. It includes consideration of economic issues, historical context, group-interest, self-interest, feelings, and the unconscious. Those who use CRT as lens for looking at social situations do so in order to gain a better understanding of the issue as well as to transform society for the better (Delgado \& Stefancic, 2001). 
While the existence of white undocumented students in the United States is possible, the vast majority is non-white. In 2008, the countries of origin for undocumented immigrants were 56\% Mexico, 22\% other Latin American nations, 13\% Asian, 6\% Europe and Canada, and 3\% Africa and other parts of the world (Gildersleeve, Rumann, and Mondragon, 2010). Critical Race Theory questions the idea of whiteness and how whiteness is legally defined. Up until 1952, immigration law identified qualifications for naturalization and citizenship which included being a white male (Delgado \& Stefancic, 2001). This historical discrimination against non-white immigrants faced makes CRT an appropriate lens through which to consider the plight of undocumented students.

One primary tenant of Critical Race Theory is that racism is ordinary; that is, it is the way society does business and is the common experience of most people of color in this country. This is one of the factors making racism so difficult to address, let alone cure, because as a society, there is a tendency to overlook the everyday acts of racism while only considering the most blatant acts of racism as appalling. Additionally, there is little incentive to eradicate racism and racist practices within society because racism advances the interests of both whites and the working middle class. Therefore, even though races are nothing more than categories invented and manipulated by society, the impact of racism is evident throughout society (Delgado \& Stefancic, 2001).

Further complicating the issue is the fact that few people have a single identity. Everyone has potentially conflicting, overlapping identities, loyalties, and allegiances. And this is the situation in which many undocumented students find themselves. Scholars of CRT consider the phenomenon of "intersectionality" wherein there is an "examination of race, sex, class, national origin, and sexual orientation, and how their combination plays out in various settings" (Delgado 
$\&$ Stefancic, p. 51). While intersectionality as a term originated in the work of feminist researcher, Kimberle Crenshaw (1983), to describe the experience of women of color or immigrant women, the term can also be applied to undocumented students. Most undocumented students find themselves identifying as having at least "triple minority status" which includes their ethnic origin, lack of documentation, and economic disadvantages (Perez, Cortes, Ramos, \& Coronado, 2010), however, the number of groups to which an individual could potentially belong is immeasurable when you consider such minority groupings as English Language Learner, gay, lesbian, bisexual, trans-gendered, female, non-white, etc. Finding consensus to stand up to oppression when individuals have multiple individual experiences with oppression coupled with the intersectionality of personal situations, requires the group to "essentialize" or drill down to the one unit at the heart of their oppression and then work together to end it (Delgado \& Stefancic, 2001). While undocumented students come from many different backgrounds, arrived at high school completion via many different paths, and hope for many different futures, they all have the commonality of being students ready to pursue post-secondary education with various ideas, or not, of how to achieve that goal.

Critical Race Theory also challenges the concepts of meritocracy and colorblindness. Districts, schools, and faculty members, in trying to be politically correct and fair, claim to have policies that reward students on merit and with colorblindness by claiming to have a neutral systems that function for all students in the same way. By learning from the educational experiences from communities of color, oppressive structures and practices have been revealed. Through this revelation of racism in education, social and racial justice efforts can increase empowerment among communities of color (Perez Huber, 2010). By ignoring the unique needs 
of undocumented students while trying to be politically correct, educators, including high school guidance counselors, do a disservice to these students.

\section{Latino Critical Theory}

An off-shoot of Critical Race Theory, Latino Critical Theory, or LatCrit, considers the intersection of racism and nativism. While Critical Race Theory emphasizes institutional racism that exists within the educational systems and judicial systems because of its focus on race, racism, and power, LatCrit extends and includes consideration of language rights, immigration, citizenship, and ethnic discrimination (Gonzalez \& Portillos, 2007). Perez Huber defines racism as the "the assigning of values to real or imagined differences in order to justify white supremacy, to the benefit of whites and at the expense of People of Color, and thereby defend the right of whites to dominance" (2010, p. 80). Nativism includes these critical components: opposition to the foreigner, protection of a nationalistic identity, and the foreigner becomes a perceived threat to the nationalistic identity (Perez Huber, 2010). When originally conceptualized, nativism specifically favored those of Anglo-Saxon descent and disparaged many groups of white immigrants as well as immigrants of color. Thus, Perez Huber defines nativism as "the practice of assigning values to real or imagined differences, in order to justify the superiority of the native, and to defend the native's right to dominance, at the expense of the non-native" (2010, p. 80). Delgado and Stefancic (2001) define nativism as the "view that the United States should give priority to current citizenry and limit immigration” (p. 151). Finally, Perez Huber combines these concepts to racist nativism defined as "the assigning of values to real or imagined differences in order to justify the superiority of the native, who is perceived to be white, over the non-native, who is perceived to be People and Immigrants of Color, and thereby defend the native's right to dominance" (2010, p. 81). 
Perez Huber argues that evidence of racist nativism exists throughout the history of the United States. Some obvious examples include the 1882 Chinese Exclusion Act as well as Mexican repatriation programs that were instituted in the 1930s and the Japanese Internment camps during World War II (2010). Racist nativism, however, is not a thing of the nation's past. Its presence can be seen as undocumented students, most of whom are non-white and all of whom are non-native, attempt to navigate college access.

Latino Critical Thought Scholars have worked to focus attention on many issues affecting Hispanic immigrants - whether they are in the United States with legal paperwork or not. Some of the most pressing injustices include issues of immigration, language rights, bilingual schooling, internal colonialism, sanctuary for Latin American refugees, and census categories for Hispanics (Delgado \& Stefancic, 2001). These scholars also argue that nativism against Latinos becomes more apparent during times of economic downturn, when the labor supply is over-full, or when other workers lack security in their jobs. Most undocumented immigrants are from Mexico or other Latin American countries (Gildersleeve, Rumann, \& Mondragon, 2010). The sad reality for many of them is feelings of humiliation and helpless because of their legal status along with a sense of shame and discrimination because of the media's often over-representation of them as illegal aliens (Perez, Cortes, Ramos, \& Coronado, 2010). Furthermore, there is significant evidence that Latino/a high school students often attend high schools with limited access to rigorous college-preparatory course work and are generally underserved by resources necessary to make a successful transition to post-secondary educational institutions (Gonzales, 2010). This combination of feeling helpless and lacking resources often results in Latino/a high school graduates, including undocumented high school graduates, eliminating the possibility of college from their plans for the future. 


\section{Social Capital Theory}

In developing his theory of Social Capital, Coleman (1988) defined social capital, not as a particular thing, but as a function with two common elements: (a) some aspect of social structures and (b) certain actions result among the actors within the structure. He asserts that social capital makes certain achievements possible, and without that social capital those ends would not be possible. Unlike physical capital which is embodied in physical form and tangible, or human capital which is less tangible yet recognizable as skills and acquired knowledge, social capital is even less tangible because "it exists in the relations among persons" (pp. S100-101). Productivity requires physical, human, and social capital. Coleman goes on to define three major forms of social capital: (a) obligations, expectations, and trustworthiness, (b) information channels, and (c) norms and effective sanctions.

Social Capital Theory claims learning and development are interdependent and culturally mediated activities (Cole, 1996; Gutierrez, 2008; Gildersleeve and Ranero, 2010). Assuming college-going literacies can be taught, a college-going pedagogy must be adopted by educators who want to support educational opportunities for undocumented youth; thus, "if college access is learned, then it can be taught" (Gildersleeve \& Ranero, 2010, p. 21). Undocumented students face many disadvantages compared to their native peers in terms of employment, social services, and basic human rights. Because of limited economic and social resources, it is no surprise they often struggle to access and attain higher education. The lack of cultural capital, that is the knowledge, skills, education and other advantages a person has that make the educational system a comfortable, familiar environment in which a person can succeed easily, is another barrier often faced by undocumented students (Gildersleeve, Rumann, \& Mondragon, 2010). 
Gonzalez (2010), concluded that social capital may be one of the most important factors in undocumented students gaining access to college. He argued that the relationships between peer networks and school officials can enable poor and minority students important access and resources for school success. Since most undocumented students are victims of poverty, racism, and substandard schooling conditions (Gildersleeve \& Ranero, 2010), this social capital becomes even more essential for the successful acquisition of college opportunities among undocumented students.

Most undocumented high school students would be classified as members of Generation 1.5. Generation 1.5 is identified as immigrant children who migrate before the age of 12 and receive most of their socialization and schooling in the United States (Rumbaut, 2004). "Because the overwhelming majority of these children outpace their parents in educational attainment, many are left without proper guidance about school" (Gonzales, 2010, p. 471). The struggle for many undocumented students is similar to the struggle many first generation college students face. High school guidance counselors have a responsibility to educate families about what it takes to successfully finish high school and move to the next level of education (Gonzales, 2010).

While utilizing social capital to assist students throughout the college access process, it is also important for guidance counselors to consider the social wealth undocumented have on their own merit. In general social capital is understood as networks of people and community resources. These networks provide both instrumental support and emotional support as individuals navigate society's institutions, including secondary and post-secondary educational institutions. By having some connection, either directly or indirectly, with people who know how to navigate various systems, a person is more likely to find success throughout the navigation 
process (Coleman, 1988). Yosso posits students of color possess five other strands of cultural wealth besides simply social capital. These other forms of capital are identified as (a) aspirational capital, that is the ability to maintain hopes and dreams for the future even in the face of real and perceived barriers, (b) linguistic capital, that is the ability to communicate in more than one language and or style, (c) familial capital, that is the cultural knowledge cultivates a sense of community history, memory, and cultural intuition, (d) navigational capital, that is the skills required to navigate through social institutions, particularly those designed to be served by the dominant society, and (e) resistant capital, that is the skills fostered through oppositional behavior and challenging oppression (2005). It is at this intersection where high school guidance counselors must work when helping undocumented students gain access to college and other post-secondary opportunities. There must be an understanding of the value of social capital throughout the entire process, yet at the same time there must be a recognition of the cultural wealth undocumented students possess. High school counselors must be guides to help undocumented students access social capital as they work with students on applications for admissions, scholarships, and financial aid; they must connect students with community members who have clout with institutions and organizations; they must help students become proficient in both written and spoken formal language. Additionally, guidance counselors have to help undocumented students present themselves as individuals who can bring something special to campus by highlighting their cultural wealth which includes a background as an immigrant, a poly-lingual speaker and writer, and an individual with a rich cultural heritage.

\section{An Intersection of Frameworks}

By considering the affects racism, racist nativism, and social capital, or lack of social capital, have on society in general and on access to higher education specifically, the focus shifts 
to how these three theoretical frameworks intersect when considering the obstacles which hinder undocumented students as they seek access to post-secondary educational opportunities. Theorists from each of these three schools of thought would agree that the undocumented high school graduates could face multiple roadblocks based on the individual's multiple identities as non-white and non-native with limited middle- or upper- class social connections. Concurrently, however, these frameworks encourage educators, including high school guidance counselors, to consider, and even highlight, the richness an individual undocumented student can bring to the broader context of higher education as well as the individual college or university institution.

Undocumented students have college advising needs quite similar to minority, first generation, and low-income students. Often they have an undeveloped sense of their postsecondary options and recognize the need for what is considered a good job, yet they cannot always define what that means. Additionally, parents of undocumented students recognize the importance of college, but need guidance from the school in order to understand the processes (Arriola \& Murphy, 2010). Thus undocumented students are likely to need the services of their high school guidance counselor to navigate this process since private college counselors charge exuberant fees for their services, making their services out of reach to the majority of undocumented students. Undocumented students often lack "cultural capital" which includes "knowledge, skills, education, and other advantages a person has that make the educational system a comfortable, familiar environment” (Gildersleeve, Rumann, \& Mondragon, 2010). Because of this, undocumented students rely on the people in their schools who have expertise in the navigation process of college-going. 


\section{High School Guidance Counselors and College Access}

In the United States, high school students navigate the college application process utilizing a variety of tools including private college counselors, the internet, family members, college counselors, and high school guidance counselors. According to the National Association for College Admission Counseling (2010), secondary school guidance counselors rate planning and preparing for postsecondary options as one of the two most important priorities. Yet they only spend a quarter of their time doing such work (School Counselors Contribute to College Access and Success, 2013). Additionally, the American School Counselor Association (ASCA) outlines their School Counselor Competencies which includes an entire section on Individual Student Planning. While this planning is not strictly for the purpose of college-going after high school, it is a major component. Competent high school guidance counselors help "students learn the importance of college and other post-secondary education and help students navigate the college admissions process" (American School Counselor Association, 2013).

While high school guidance counselors have historically struggled to make college advisement a part of their work, that is changing dramatically. Research shows that school counselors can make a positive impact on students' aspirations, achievements and financial aid knowledge. In order to have that impact, however, guidance counselors must be able to provide direct services to students and their families both frequently and regularly (McDonough, 2005). Large case-loads and other demands of the job often make college advising difficult for high school counselors, however, with increased focus on college-readiness in order to prepare a welltrained workforce, the demand for such work is on the increase. The American School Counselor Association (ASCA) recommends that school counselors spend up to 70 percent of their time providing direct services to students, which could include college advising, yet gathering 
accurate data on how much time counselors actually spend doing college advising is extremely difficult and seems to be nearly impossible to measure. According to a study by the National Center for Educational Statistics, only 43 percent of guidance counselors at public high schools spent 20 percent or more of their time on college counseling. Consider converse of the statistic. Fifty-seven percent of guidance counselors in public high schools spent 0-19 percent of their time doing college advising (U.S. Department of Education, 2004).

While searching for, applying to, and navigating financial aid is an important part of college advising, it is not the only critical role guidance counselors play in this college-going process. The pathway to college really begins in pre-school; skills built in elementary school and middle school are critical to college readiness. High school guidance counselors, however, play a critical role as they help students select courses and progress toward their aspirations (McDonough, 2005). According to Martinez and Klopott (2003), in order to best assist minority, low-income, and first generation college students in the college-going process, a complete reinvention of current middle and high school systems may be required. High school guidance counselors will play an significant role in assuring undocumented students are well-prepared and have access to information about college and enroll in high school courses that will provide adequate preparation for college-level work. Students who are in the United States without proper legal documentation are often a sub-group within this larger group of minority, lowincome, and first generation college students. As such, guidance counselors are increasingly critical in helping undocumented students navigate high school in order to be college ready. 
The Law and Undocumented Students

Many undocumented students express feelings of being essentially invisible within American society. Common activities offered to legal residents and citizens including the ability to work, drive, and travel on airplanes are off limits (Arriola \& Murphy, 2010). Educators, including high school guidance counselors, must realize the affects these limitations have on the confidence of undocumented students and their families as they consider the possibility of college. For many, going through the search and application process feels futile since, like so many other activities, going to college is likely to be denied. "Undocumented students reside in two parallel worlds: one which requires them to keep secrets about family issues such as legal residency and sources of income; and anther which asks them to believe in the power of education to change their circumstances" (p. 27).

A common misconception among the American public is that most undocumented residents of the United States are people who stole across the border in the dark of night. Propaganda tools from militia groups in the southwestern part of the country send the message about dangerous illegals with intentions of doing harm to the nation must be stopped no matter the cost. The reality is many undocumented families arrived in the United States under much less sinister circumstance. Employment is most common reason immigrants come to the United States. Although many arrive through illegal means, there is a culture within certain industries, including agriculture and meat processing, that encourages immigrants to recruit family members and friends to enter the country to provide a work force. Furthermore, it is not that uncommon for workers, either alone or with their families, to enter the United States with proper documentation, but when visas expire, factors including language barriers, long-working hours, and transportation issues, prevent them from maintaining legal status (Drachman, 2006). 
Educators, including high school guidance counselors, need to understand immigration issues and how their undocumented students came to have that status. It is really important for all Americans, but educators in particular, to recognize undocumented immigrants as a "valuable national resource that should be tapped rather than rejected" (p. 99).

\section{The High School Counselor's Role}

Society in general, and educators, including high school guidance counselors, specifically, recognize that while there is a cost to education, the benefits outweigh them. This holds true when considering the education of undocumented students. When states have decided to enact the DREAM Act, legislators have considered that cost vs. benefit. While allowing undocumented students to attend a public college or university and pay in-state resident tuition does create a true financial cost to the state, in the long run, the monetary benefits make the initial investment seem well worth it. By investing in a college degree, the state reduces the chances of the student needing government assistance later in life, increases the individual's future earning potential, thus tax-paying potential, and adds to the educated work-force.

Likewise, there are non-monetary costs and benefits to allowing undocumented students access to resident tuition including reductions in psychological stress, increase in public and social prestige, and overall better emotional and physical health (Flores, 2010).

While American educators, including high school guidance counselors, want to help all students, including those who are undocumented achieve their college aspirations, obstacles often times seem insurmountable. Furthermore, guidance counselors and teachers often have no control over state policies, tuition costs, or individual college practices concerning citizenship documentation, yet there are practical steps that can help undocumented students navigate 
college access. Helping students learn college-going literacies is a practical approach that can help all students who feel blocked from college. When working with Mexican migrant students, Gildersleeve and Ranero (2010) posit, "college-going trajectories can be documented as collegegoing literacy development, underscoring the practical sense-making dimensions to how students are involved in their educational achievements" (p. 21). Literacy is something learned; therefore something taught. As such, "if college access is learned, then it can be taught (p. 21). As such, a college-going pedagogy should be adopted by educators who want to support the college going opportunities for undocumented students.

Navigating the college admission process is a daunting task for any student, but especially for a student who is in the United States without proper and legal paperwork. While gaining college admissions often takes priority early in the process, undocumented students face more issues when it comes to financing their education. Undocumented students are not allowed to use federal dollars (PELL grants and subsidized loans) to pay for post-secondary educational expenses and in most states, undocumented students must pay non-resident tuition rates (out-ofstate), these students are often driven away from some of the most affordable educational opportunities available which include community colleges, regional, and state institutions. If students are residents of a DREAM Act state and do qualify for resident tuition rates, it is essential for high school counselors to understand how best to advise them in order for them to access scholarships and aid. As stated earlier, undocumented students do not qualify for federal financial aid to help pay for college, even in DREAM Act states. Therefore, high school counselors should never advise an undocumented student to file a Free Application for Federal Student Aid (FAFSA) with the government. However, if the student has become a citizen or legal resident, he or she can apply for aid (Illinois Coalition for Immigrant and Refugee Rights, 
2012). Yet, without proper training and education about the laws, high school guidance counselors in both DREAM Act and non-DREAM Act states could potentially misadvise an undocumented student.

An understanding of the contexts from which undocumented students come is an essential piece of the practice for high school guidance counselors. Recognizing and sympathizing with an undocumented student is not enough to help that student find success in a college setting. Considering the family context, schooling context, and educational achievement expectations can allow guidance counselors to better assist undocumented students (Gildersleeve \& Ranero, 2010). The family structure of an undocumented student will likely be very different from the middle class American family structure. The family organization is likely to be comprised of various family members who may or may not be related. Additionally, each person within the family will have his or her own immigration story. Most undocumented students will be from working class or poor families and can include all aspects of poverty. The schooling structure is another important consideration. Some undocumented students will struggle with mastery of English, particularly English as an academic language. Others will struggle because of discontinuity in their education, especially if they are from families who have done migratory farm work. Finally, some students will underachieve academically because school curriculum is presented in ways unfamiliar to their social and cultural contexts. This can be a real struggle for high school students as they prepare for college entrance examinations which have been long been accused of cultural bias (Gildersleeve \& Ranero, 2010).

Finally, daily work done with and for undocumented students by their guidance counselors will be guided by the same ethical principles which guide their work with all students. By having an open mind and creating an open space which sends the message to all students that 
college is an option allows undocumented students to feel comfortable seeking advice about college as a possibility. It is essential for guidance counselors to understand federal laws and the laws of their state and resources available to undocumented students who graduate from their high school. Finally, guidance counselors should work to include families in the college going process. For many that will mean providing information sessions in languages other than English or inviting translators to attend individual planning meetings (Illinois Coalition for Immigrant and Refugee Rights, 2012).

Laws for Primary and Secondary Education

Federal law requires certain rights and privileges to people in the United States without documentation. While certainly subject to interpretation and debate, there are clear guidelines about some educational policies for undocumented students who are in primary or secondary school. The law is more ambiguous when it comes to post-secondary educational opportunities.

According to the Fourteenth Amendment to the Constitution, people who are in the United States without documentation do have legal rights including the right to emergency health care; emergency shelter; disaster aid; due process related to unlawful search and seizure, arrest, and work related discrimination and unfair labor practices; and unfair housing discrimination (Gildersleeve, Rumann, \& Mondragon, 2010). Additionally, there are no laws that restrict undocumented immigrants from opening bank accounts, taking out private loans, or purchasing private health insurance (Gildersleeve, Rumann, \& Mondragon, 2010). In 1982, the Supreme Court confirmed that children of undocumented immigrants have the right to seek a public K-12 education in its landmark decision Plyler v. Doe. The court, however, did not address the issue of matriculation to institutions of higher education (Gildersleeve, Rumann, \& Mondragon, 2010; 
Drachman, 2006). The two sides of this on-going debate were solidified in the Plyler v. Doe case. The Majority opinion concluded denying access to a free public education created an entire class of people who would be disabled because of their illiteracy while the dissenting opinion argued since undocumented students are not in the United States legally, then the government has no responsibility to provide government services (Drachman, 2006). These two opposing opinions continue to divide ideologies on the subject of educating undocumented students at the post-secondary level.

Laws for Post-secondary Education

There are several laws regarding this issue that continue to spark heated debated concerning undocumented access to higher education. The two most important federal laws are Illegal Immigration Reform and Immigrant Responsibility Act of 1996 (IRIRA) and the Personal Responsibility and Work Opportunity Reconciliation Act of 1996 (PRWORA). What is clear about these two laws is that undocumented students seeking higher education do not have access to federal financial aid. What, however is unclear, is whether or not states have the right to allow undocumented students to attend public universities and pay in-state resident tuition rates (Gildersleeve, Rumann, \& Mondragon, 2010; Drachman, 2006). According to Gildersleeve, Rumann, and Mondragon, "Although no federal legislation prevents undocumented students from attending higher education, some states and individual institutions have taken action to contest or deny undocumented admissions." Furthermore, "there is no uniform set of standards for undocumented students' admission and access to higher education across the board, and rules and regulations vary considerably by state" (p. 10). 
The Development, Relief, and Education for Alien Minors (DREAM) Act was first introduced in 2001. Its original purpose was to clarify offering in-state resident tuition to undocumented students and provide a pathway for citizenship. The current version of the DREAM Act would follow a two-step process toward legal residency. First, young people would have a conditional status for six to eight years while either pursuing higher education or serving in the military. Then, after two years of college or military service, they could apply for permanent residency. Other conditions must also be met in order for students to meet the requirements outlined in the DREAM Act. Students must have entered the country before they turned 16 years old; they must have lived in the United States for at least five years; they must have been admitted to a post-secondary institution; they must have earned a high school diploma or General Education Diploma (GED); and they must have "good moral character" (Gildersleeve, Rumann, \& Mondragon, 2010).

\section{SUMMARY}

Throughout Chapter Two the researcher provided a review of literature concerning this research study about the exploration of the knowledge high school guidance counselors have to assist undocumented students gaining access to college This chapter was divided into four sections covering the following topics: (a) an introduction to the study, (b) the conceptual underpinnings guiding the study including Critial Race Theory, Latino Critical Theory, and Social Capital Theory, (c) high school guidance counselors and their role in college access, and (d) undocumented students and their access to college through the work of high school guidance counselors, the laws concerning their primary and secondary education, and the laws concerning their post-secondary educational opportunities. 
Chapter Three will provide the methodology that will be used in the study and will include research questions, information about the population sample, data collection and analysis. Chapter Four will provide a detailed description and analysis of the gathered data. Chapter Five will include a summary of the findings, the limitations of the study, and the implications for future research. 


\title{
CHAPTER THREE
}

\section{RESEARCH DESIGN AND METHODOLOGY}

\author{
Introduction
}

When considered as a minority group, undocumented are unique in that they are often victims of "triple minority status" based on their ethnic origin, their lack of documentation, and their economic disadvantages (Perez, Cortes, Ramos, \& Coronado, 2010). Undocumented students who want to attend college face multiple barriers including legal status, federal laws, and limited financial resources. Furthermore, many undocumented students do not have the high school preparatory background to successfully prepare them for the rigors of college-level work. This is especially true among Latinos, which makes up the largest non-white ethnic group in the United States. Latino students tend to attend high schools that do not have the resources to prepare them for college. Lack of access to supplies, rigorous course-work, highly qualified teachers, and adequate facilities creates a disadvantage to college-readiness (Zarate \& Burciaga, 2010). Many undocumented students struggle with the same factors that other low-income minority students face, including poverty, violence, lack of resources and discrimination. Additionally, they have the burden of not being provided the protection available to legalized immigrants and American citizens. This can result in feelings of anxiety, disappointment, rejection, and helplessness (Perez, Cortes, Ramos, \& Coronado, 2010).

Many of the aforementioned issues are often addressed by high school guidance counselors. The American School Counselor Association identifies school counselor competencies aimed at insuring adequate post-secondary preparation for all students. This would 
include students who do not have legal documentation to reside in the United States. Consider the list of competencies from section I-C: Attitudes:

I-C-1. Every student can learn, and every student can succeed

I-C-2. Every student should have access to and opportunity for a high-quality education

I-C-3. Every student should graduate from high school and be prepared for employment or college and other post secondary education (American School Counselor Association, 2013).

With these prescribed competencies in mind, it seems natural for high school counselors to work hand in hand with undocumented students throughout their high school experience as they select courses and prepare for their futures.

\section{Problem and Purpose Overview}

Although between 50,000 and 65,000 undocumented students graduate from high schools in the United States every year, many are not going on to seek post-secondary educational opportunities at colleges and universities (Gildersleeve \& Ranero, 2010). Attending college, earning a degree, and finding a career can provide hope for undocumented students in that "company sponsorships [may be] the only realistic opportunity of achieving legal status in the United States" (Ortiz \& Hinojosa, 2010, p. 54). Navigating the college admission process is a daunting task for any student, but especially for a student who is in the United States without proper and legal paperwork. While navigating college admissions often takes priority early in the process, undocumented students face more issues when it comes to financing their education. Undocumented students are not allowed to use federal dollars (PELL grants and subsidized loans) to pay for post-secondary educational expenses and in most states, undocumented students must pay non-resident tuition rates (out-of-state), these students are often driven away from some 
of the most affordable educational opportunities available which include community colleges, regional, and state institutions.

High school guidance counselors who are frequently and consistently available to provide direct services to students and their families concerning college readiness and admissions have a great impact on aspirations, achievement, college enrollment, and financial aid knowledge. This is especially true in schools that serve minority, low-income, and first generation college students (McDonough, 2005). Most undocumented students fit into one, if not all of these categories. Furthermore, high school guidance counselors have an ethical obligation to serve all students without regard to race, ethnicity, socio-economic status, or immigration status (American School Counselor Association, 2013).

\section{Purpose of the Study}

The purpose of the study was to explore the knowledge high school guidance counselors in Missouri have to assist undocumented students attempting to gain access to college. Guidance counselors play a pivotal role in the college-going process for many public high school students (School Counselors Contribute to College Access and Success, 2013) and the number of undocumented students who are graduating from high schools in the United States continues to rise (Gildersleeve, Rumann, \& Mondragon, 2010). Therefore, gaining an understanding about guidance counselors and their knowledge gaps concerning college access for undocumented students is essential in understanding how high school guidance counselors can best serve the undocumented students on their case load. Furthermore, by understanding the knowledge high school guidance counselors both have and lack, considerations for pre-service and in-service training can be impacted. 


\section{Research Questions}

Researchers seek to develop research questions by analyzing the literature to understand what knowledge is missing and then to add to the body of knowledge (Creswell, 2003). Through careful analysis of the literature concerning the responsibilities of high school guidance counselors and the plight of undocumented students, especially in states where the DREAM Act is not the law, the following research questions emerged to guide this study:

1. What knowledge do high school guidance counselors in Missouri have to assist undocumented students attempting to gain access to college?

2. What knowledge do high school counselors in Missouri lack to assist undocumented students attempting to gain access to college?

\section{Population and Sample}

The Development, Relief, and Education for Alien Minors (DREAM) Act was first introduced in 2001. Its original purpose was to clarify offering in-state resident tuition to undocumented students, and provide a pathway for citizenship for undocumented students. The current version of the DREAM Act would follow a two-step process toward legal residency. First, young people would have a conditional status for six to eight years while either pursuing higher education or serving in the military. Then, after two years of college or military service, they could apply for permanent residency. Other conditions must also be met in order for students to meet the requirements outlined in the DREAM Act. Students must have entered the country before they turned 16 years old; they must have lived in the United States for at least five years; they must have been admitted to a post-secondary institution; they must have earned a high school diploma or General Education Diploma (GED); and they must have "good moral 
character" (Gildersleeve, Rumann, \& Mondragon, 2010). Currently twelve states have adopted a version of the DREAM Act; California, Illinois, Kansas, Maryland, Massachusetts, Nebraska, New Mexico, New York, Texas, Utah, Washington, and Wisconsin (Arriola \& Murphy, 2010).

The population for this study was high school guidance counselors in a mid-sized district in a Midwestern City. This group of guidance counselors work, although might not live, in a state that has not authorized a version of the DREAM Act. Therefore, these counselors are not working with students who have the opportunity to seek higher education at the in-state resident tuition rate. The district has four high schools that include sections of the metropolitan area that would be considered either urban or suburban.

To complete this research project, the researcher began by analyzing documents produced and or utilized by the guidance counselors in this district which identify practices and procedures for assisting students as they gain access to college. The researcher continued by interviewing several individual high school guidance counselors from the identified district. Additionally, the researcher conducted several focus groups to gather information. Some of the focus groups consisted of high school guidance counselors who work at schools with a demographic that includes a higher possibility for undocumented students than others. Finally the researcher observed counselors presenting information to students and families as they prepare to gain access to college and other post-secondary opportunities.

\section{The Use of Case Study}

The purpose of the study is to explore the knowledge of high school guidance counselors as they assist undocumented students attempting to gain access to college. As such, gaining an in-depth understanding of the practices of high school guidance counselors as they work with 
undocumented students through the college application process is essential. Thus the use of case study is appropriate. The exploratory nature of case study allows for in-depth understanding about the details of a program (Merriam, 1998). Case studies are particularistic, that is, focused on a particular situation; descriptive, that is, filled with "rich and thick" (29) description; and heuristic, that is, laden with new meaning and understanding about the phenomenon being studied. Additionally, qualitative data are descriptive and tell a detail-filled story. "They capture and communicate someone else's experience of the world in his or her own words" (Patton, 2002, p. 47).

\section{The Tools of Case Study}

The data collection methods of case study are varied and include document analysis, individual interviews, observations, and focus groups (Merriam, 1998). The researcher for this study used all of these tools in order to gather information to answer the research questions.

\section{Document analysis}

Document analysis can be used to identify important issues and are a rich source of information about different organizations and their programs. Additionally, program records can provide insight to program processes and how those processes evolved over time. There are certainly challenges researchers face when analyzing documents including gaining access to the documents, understanding how and why the documents came to be, determining the accuracy of the documents, linking the documents to other data sources, and deconstructing to understand texts specific to the institutions from which they come (Patton, 2002). Furthermore Merriam warns researchers to avoid using documents in isolation. After determining authenticity of a document, qualitative researchers can determine whether or not the document has information or 
insights to help answer the research question (1998). Likewise, qualitative researchers must recognize the limitations of documents as a research tool. First, documents were likely not created with research purposes in mind, and therefore, may be incomplete for such purposes. Second, documents may not be in a form that is useful to researchers. Finally, determining authenticity and accuracy can be extremely difficult especially if there was some sort of bias, whether intentional or unintentional, in the recording that does not appear evident to researchers (Merriam, 1998).

\section{Interviews}

Another tool of case studies is the interview. Interviews allow qualitative researchers to access data which is not observable. It allows for insight into another person's perspective. Thus the challenge for interviewers is to create a setting where the people interviewed will allow them into their world. Consequently, Patton warns the qualitative researcher, "The quality of the information obtained during an interview is largely dependent on the interviewer" $(2002$, p. 341). Patton identifies five basic types of interviews: the informal conversational interview, the interview guide, the standard open-ended interview, a closed-fixed response interview, or a combination of two or more of the above approaches. Each approach to interviewing has its own strengths and weaknesses which can contribute to the quality of data gathered from the interview (Patton, 2002). Merriam, however, identifies types of interviews along a continuum from highly structured/standardized interviews, to semistructured interviews, to unstructured/informal interviews. While each type of interviewing has its place in the world of qualitative research, "the unstructured interview is often used in conjunction with participant observation in the early stages of a case study" (1998, p. 75). Because few researchers do only one type of interviewing, however, Merriam recommends a combination of the three types of interviews be used so 
standardized information can be gathered, so all participants have the opportunity to answer some open-ended questions, and so fresh information can emerge from unstructured, conversational interviews (Merriam, 1998).

\section{Focus groups}

Another tool often used in case study is focus groups. Using a focus group as a method for qualitative research allows researchers to gain understanding by entering an environment that allows participants to "share perceptions and points of view without pressuring participants to vote or reach consensus" (Krueger and Casey, 2000, p. 4). When conducting focus groups, there are several key guidelines researchers should follow. First, researchers should carefully consider the size of the group. Focus groups should be made of five to ten people - small enough to allow for everyone to participate yet large enough to have diversity within the group. Second, a moderator should carefully plan the discussion and questions to include and an opening, introductory, transition, key and ending questions. The moderator should guide the discussion from general to specific questions while using the available time wisely. Finally, researchers should plan three or four focus groups with particular types of participants. By doing this, researchers can determine if they are getting additional new information or if they have reached a point of saturation in that new ideas and information are not coming out the focus groups (Krueger \& Casey, 2000).

\section{Observation}

Observation is a final key tool used in case study. There are two main distinctions between interviews and observations. First, observations occur in a natural setting or field. Second, observations allow for the researcher to gain firsthand knowledge about the subject 
being investigated rather than hearing or reading a secondhand report of something that already happened (Merriam, 1998). There are, however, both advantages and limitations when using observation as a tool. Advantages of observation for the qualitative researcher include the prospect to have a firsthand experiences with participants, the ability to record information as it is revealed, the opportunity to notice unusual aspects of the phenomena under study, and insight as to how best to explore topics with the potential to make participants feel uncomfortable. Limitations of observation include the possibility the researcher will be viewed as intrusive, certain information of a private nature may be observed, but not ethically reported, the researcher may not possess necessary attending and observational skills, and the researcher may have trouble gaining rapport with participants (Merriam, 1998).

\section{Data Analysis in Case Study}

While the tools of case study including document analysis, individual interviews, observations, and focus groups are the means for gathering data, researchers use the data after careful coding and analysis. As Merriam (1998) states, however, the primary tool for any qualitative research is the researcher. "Certain characteristics differentiate the human researcher from other data collection instruments" (p. 7). Therefore, it is essential for the researcher to be responsive to the context, adaptable to the circumstances, and sensitive to the nonverbal aspects of data analysis (1998).

\section{Document analysis}

Analyzing documents requires researchers to develop a systematic approach to describe the content of the documents (Merriam, 1998). Furthermore, researchers must remember understanding institutional documents and texts is one way they can understand the institution 
and its authority (Patton, 2002). The first step in analyzing documents is finding relevant documents. An additional aspect of utilizing documents in research includes determining the authenticity and accuracy of the documents.

\section{Interview Analysis}

In order to analyze data gathered through interviews, researchers record those conversations and transcribe them. Early in the data gathering stage, researchers should transcribe interviews verbatim to avoid overlooking key insights. Later, however, using an interview log that highlights the main points of the interview may be acceptable and could simplify some data analysis (Merriam, 1998). One way of analyzing data gathered through interviews is to do cross-case analysis by grouping together answers given by different people to the same questions. This approach works best when researchers use a standardized open-ended interview (Patton, 2002). Additionally, researchers should consider more than just the content of the interview, but also the quality of the data obtained. Researchers should note various factors that could influence the respondents' responses, such as health and mood at the time of the interview, might affect the quality of the data. Similarly, respondents may have ulterior motives for participating in the project that influence the information they choose to share and that they choose to withhold (Merriam, 1998).

\section{Focus group analysis}

Like interviews, focus groups require verbatim transcription of everything said. One problem faced by researchers using data gathered from focus groups is the vast amount of data they have. As such, it is essential for researchers to remain focused on the intent of the study and to use the data which provides insight to the purpose of the research. This is not to say 
researchers are not open to new revelations emerging from focus groups, however, it is a warning to avoid going off track and focusing on data that does not move the purpose of the research forward (Krueger \& Casey, 2000). Additionally, "focus group analysis is systematic, sequential, verifiable, and continuous" (p. 128).

\section{Observation analysis}

During observations, researchers take field notes in order to capture what is happening in the setting. While field notes vary from researcher to researcher, some central tenants of taking field notes include paying careful attention, moving focus back and forth between individuals and the whole group, listening for key words, concentrating of the first and last remarks of a conversation, and mentally replaying scenes or conversations during breaks (Merriam, 1998).

Field notes are much more than just a verbatim recitation of the words said during an observation. This is the chance for the data gatherer to retell the story he or she observes. Thus it is an interpretive process that takes in every observable aspect of the setting (Patton, 2002).

\section{Theme development}

An essential element of analyzing qualitative data is the theme development. Themes are selected and priority is given after substantial amount of data has been collected and which reflect recurrent patterns of activities in a particular setting under study (Emerson, Fretz, \& Shaw, 1995). Merriam clarifies how themes emerge through the analysis of documents and transcripts from interviews, focus groups, and observation field notes. Using multiple methods of and sources for data collection to indentify and confirm those emergent themes is defined by Merriam as triangulation (1998). Four types of triangulation contributing to verification and validation of qualitative analysis: methods triangulation to check consistency of findings from 
varying methods; triangulation of sources to check the consistency of different data sources using the same method; analyst triangulation to review findings using multiple analysts to review findings; and theory or perspective triangulation to interpret data using multiple perspectives or theories (Patton, 2002).

\section{Summary}

Throughout Chapter Three the researcher provided a rationale for the use of qualitative research methodology to explore the knowledge of high school guidance counselors in Missouri as they assist undocumented students attempting to gain access to post-secondary educational opportunities. This chapter was divided into five sections covering the following topics: (a) an overview of the problem and purpose of the study (b) an identification of the study participants as high school guidance counselors in a large metropolitan school district, (c) a rationale for the use of case study, (d) a description of the tools of case study, (e) and a protocol for analyzing data gathered through case study were provided.

Chapter Four will include a detailed description and analysis of the gathered data. This will include a description of the study design and the data collection methods, a recap of the conceptual underpinnings and the research questions, a description of the process of data analysis and collection methods, a description of the setting and the participants, and a discussion of the emergent themes. Chapter Five will include a summary of the findings, the limitations of the study, and the implications for future research. 


\section{CHAPTER FOUR}

\section{PRESENTATION AND ANALYSIS OF DATA}

Introduction

The purpose of this study was to explore the knowledge high school guidance counselors in Missouri have when assisting undocumented students attempting to gain access to college. By utilizing the tools of case study and the theoretical frameworks Critical Race Theory, Latino Critical Theory, and Social Capital Theory to look at four high school counseling departments within one suburban, northwestern Missouri school district, the researcher hoped to gain an understanding of this topic. Gaining an in-depth understanding of the practices of high school guidance counselors as they work with undocumented students through the college application process was essential to this project. Therefore, using the tools of case study, which included document analysis, interviews, focus groups, and observations were appropriate. The exploratory nature of case study allows for a deep understanding of a program and allows for what Merriam (1998) terms descriptive data that is "rich and thick" (29). Additionally, qualitative data, including case study, is descriptive and tells a story. It allows the researcher to "capture and communicate someone else's experience of the world in his or her own words" (Patton, 2002, p. 47).

This chapter will first explain the study design and describe the data collection methods utilized to gather the information. The next section will include a review the conceptual underpinnings that guided the study which are Critical Race Theory, Latino Critical Theory, and Social Capital Theory. The next section will be a discussion of the research questions followed by a detailed description of the data analysis process. Because of the nature of case study, there will also be a presentation of the setting and participants for the study. The final section will be a 
detailed analysis of qualitative data that was gathered with a final discussion of the emergent themes.

\section{Study Design}

The purpose of the study was to explore the knowledge of high school guidance counselors in Missouri as they assist undocumented students attempting to gain access to college. As such, gaining an in-depth understanding of the practices of high school guidance counselors as they work with undocumented students through the college application process is essential. Thus the use of case study was appropriate. The exploratory nature of case study allows for indepth understanding about the details of a program (Merriam, 1998). Case studies are particularistic, that is, focused on a particular situation; descriptive, that is, filled with "rich and thick" (29) description; and heuristic, that is, laden with new meaning and understanding about the phenomenon being studied. Additionally, qualitative data are descriptive and tell a story. “They capture and communicate someone else's experience of the world in his or her own words" (Patton, 2002, p. 47).

To gain an understanding about the knowledge high school guidance counselors in Missouri have when assisting undocumented students attempting to gain access to college, the researcher chose to do a case study of four guidance counseling departments in one suburban northwestern Missouri school district. The researcher collected documents pertaining to college access from each of the four high schools as well as from the entire district. Then, the researcher arranged to meet each of the counseling departments to conduct a focus group discussion. Upon invitation, all of the department chairs asked to include other student services personnel who assist with the college-going process. All four high schools decided to invite their gifted resource 
teacher. Two of the high schools, who have a Missouri College Advising Corps college advisers on campus, requested to include them as well. The researcher made arrangements to complete individual interviews with some of the high school personnel who work with college access. Finally, the researcher requested to attend presentations for students and families concerning college access. For the entire case study, the participants included 15 Missouri certified high school guidance counselors, three gifted resource teachers and two college advisers. The college advisers are recent graduates of the University of Missouri. They have a Bachelor's degree and about six weeks of specialized training in college access methods.

\section{Data Collection Methods}

Before any data collection began, the researcher secured permission from the district gatekeeper to conduct the study in the high school guidance departments throughout the district. The researcher began gathering documents concerning college access throughout the district. Simultaneously, the researcher sent email request to each high school's guidance department requesting an opportunity to set up focus groups with each department and individual interviews with one or more counselors at each high school. After letters of consent were signed by all participants, arrangements were made to conduct four different focus groups and three individual interviews. Additionally the researcher made arrangements to attend some presentations counselors were facilitating for parents and or students to disseminate information about college access.

The documents collected were analyzed looking for information concerning college access for students as well as specific information concerning college access for undocumented students. Public documents are often a good source of qualitative data. Creswell (2003) suggests 
qualitative researchers can benefit from utilizing documents because they can discover the language of the participants, access information without being intrusive, and gather data that has been thoughtfully compiled. Additionally, document analysis eliminates the need for transcription. Furthermore, documents are often essential at the beginning of any sort of fieldwork so the researcher has access to that which cannot be observed (Patton, 2002).

Both the focus groups and individual interviews were recorded and transcribed verbatim. Those who participated in the interviews were given the opportunity to look over the transcriptions and to provide feedback or modifications to their answers. This procedure, called member-checking, reduces bias from the researcher by allowing participants to clarify meaning (Cresswell, 2003).

The researcher kept detailed field notes while observing three different presentations on the college application process. The researcher analyzed these field notes with particular attention to information concerning undocumented students gaining access to college.

\section{Conceptual Underpinnings}

The conceptual underpinnings guiding this study were Critical Race Theory, Latino Critical Theory, and Social Capital Theory. These three theoretical frameworks force educators to consider the affects racism, racist nativism, and social capital, or lack of social capital, have on society in general and on access to higher education specifically. For high school guidance counselors, the focus shifts to how these three theoretical frameworks intersect when considering the obstacles which hinder undocumented students as they seek access to post-secondary educational opportunities. Theorists from each of these three schools of thought would agree that the undocumented high school graduates could face multiple roadblocks based on the 
individual's multiple identities as non-white and non-native with limited middle- or upper- class social connections. Concurrently, however, these frameworks encourage educators, including high school guidance counselors, to consider, and even highlight, the richness an individual undocumented student can bring to the broader context of higher education as well as the individual college or university institution.

Undocumented students have college advising needs quite similar to minority, first generation, and low-income students. Often they have an undeveloped sense of their postsecondary options and recognize the need for what is considered a good job, yet they cannot always define what that means. Additionally, parents of undocumented students recognize the importance of college, but need guidance from the school in order to understand the processes (Arriola \& Murphy, 2010). Thus undocumented students are likely to need the services of their high school guidance counselor to navigate this process since private college counselors charge exuberant fees for their services, making their services out of reach to the majority of undocumented students. Furthermore, undocumented students often lack "cultural capital" which includes "knowledge, skills, education, and other advantages a person has that make the educational system a comfortable, familiar environment" (Gildersleeve, Rumann, \& Mondragon, 2010). Because of this, undocumented students rely on the people in their schools who have expertise in the navigation of the college-going process.

\section{Research Questions}

Researchers seek to develop research questions by analyzing the literature to understand what knowledge is missing and then to add to the body of knowledge (Creswell, 2003). Through careful analysis of the literature concerning the responsibilities of high school guidance 
counselors and the plight of undocumented students, especially in states where the DREAM Act is not the law, the following research questions emerged to guide this study:

1. What knowledge do high school guidance counselors in Missouri have to assist undocumented students attempting to gain access to college?

2. What knowledge do high school counselors in Missouri lack when assisting undocumented students gain access to college?

\section{Process of Data Analysis}

Initially the researcher gathered several documents. Some of the documents are utilized throughout the school district while others were specific to the individual high schools. Analyzed documents included the district-wide Program of Studies book, district-wide Personal Plans of Study forms and Graduation Progress forms, school specific high school profiles, power point presentations related to college access, and newsletters. Each of the documents were analyzed looking for detailed information about college access for students in general and detailed information about college access for undocumented students in particular. (See appendix $\mathrm{C}$ for a complete list of documents used). The researcher kept notes and identified the data using a coding system to identify information about college access in general and undocumented students. Merriam (2003) encourages qualitative researchers to start data analysis early in the data collection process and continuously work on analysis throughout the collection process. As such the researcher returned to gather documents multiple times and acquired additional documents throughout the process of data collection. Eventually the researcher added a third piece of data gathered from documents which was information concerning students' immigration status. 
Next, arrangements were made to conduct focus group discussions. Initially the researcher had planned to combine two different high schools together in order to have some diversity within the membership of the focus group. Because of scheduling constraints and requests from the individual department chair-persons, however, the researcher conducted four different focus groups, one at each of the four high schools. Before the focus group discussions took place, focus group members were given a letter of informed consent with a description of his or her rights. All participants signed the letter and agreed to participate. The focus group discussions were audiotaped. Later the researcher transcribed the conversations for analysis. Krueger and Casey (2000) encourage inexperienced qualitative researchers to utilize a full unabridged transcription of focus group conversations rather that to utilized tape-based, notebased, or memory-based analysis as these other approaches are "only for someone with a thorough understanding of the purpose of the study" or might be "best left to professionals" (p.131).

After each focus group was transcribed, the researcher identified common points of discussion. Using the process described by Krueger and Casey (2000) as the long-table approach, the researcher began by grouping similar ideas together. The coding scheme evolved throughout the process and included the following categories (a) college access in general, (b) knowledge about undocumented students, (c) knowledge about laws concerning undocumented students, (d) experiences with undocumented students (e) stereotypes concerning undocumented students, (f) frustrations high school guidance counselors have, and g) needs high school guidance counselors have. Eventually these codes led to the emergence of the three themes: (a) lack of awareness, (b) lack of knowledge, and (c) lack of training. 
During the same few weeks the focus group discussions were being conducted, the researcher also made arrangements to attend three different presentations about the college-going process. The presentations were evening presentations and were designed for both students and parents to attend. The first presentation was entitled "College Readiness" and was held at South High School. The presenters were two college advisers. The second presentation was entitled "College for Athletes." It was held at North High School. The presenter was an expert on college recruiting. The final presentation was also held at North High School; however, it was a districtwide presentation. The title of the presentation was "Mizzou $2 \mathrm{U}$ " and was for any student throughout the entire district interested in attending the University of Missouri - Columba.

During the presentations, the researcher took detailed field notes about the setting, the speaker, the audience, the visual aids, and the interactions among the people. Each of the three presentations lasted between 50 and 75 minutes. Ethnographic field notes allow the researcher to turn observation into data (Emerson, Fritz, \& Shaw, 1995). The researcher returned to the coding procedures utilized with the focus group transcriptions to analyze the data gathered from the observations.

Additionally during this time period, the researcher made arrangements to meet individually with three high school counselors to conduct interviews. Interviews are an appropriate means to gather data when direct observation is not possible (Creswell, 2003). Because of the nature of the research project, the researcher recognized that it would not be appropriate to observe a counselor working directly with an identified undocumented student. Therefore, to gain a better understanding of some individual counselors' experiences with undocumented students, the researcher opted for this method of gathering data. Like the focus group discussions, the interviews were audio-recorded and transcribed. Additionally, the 
transcriptions were returned to the interviewees to confirm the researcher's accurate understanding.

As with the observational field notes, the transcriptions of the interviews were taken through the same process of coding as the focus group discussions. The interview transcriptions confirmed the emergent themes that became evident during the analysis of the focus groups.

Figure 1 provides a visual for how the researcher processed the data in order to identify the three emergent themes. Because the focus group discussions provided the most abundant information for this study, the categories for coding were identified first when considering the data from transcriptions of the discussions. Data gathered from observations, interviews, and document analysis were categorized based on those established categories.

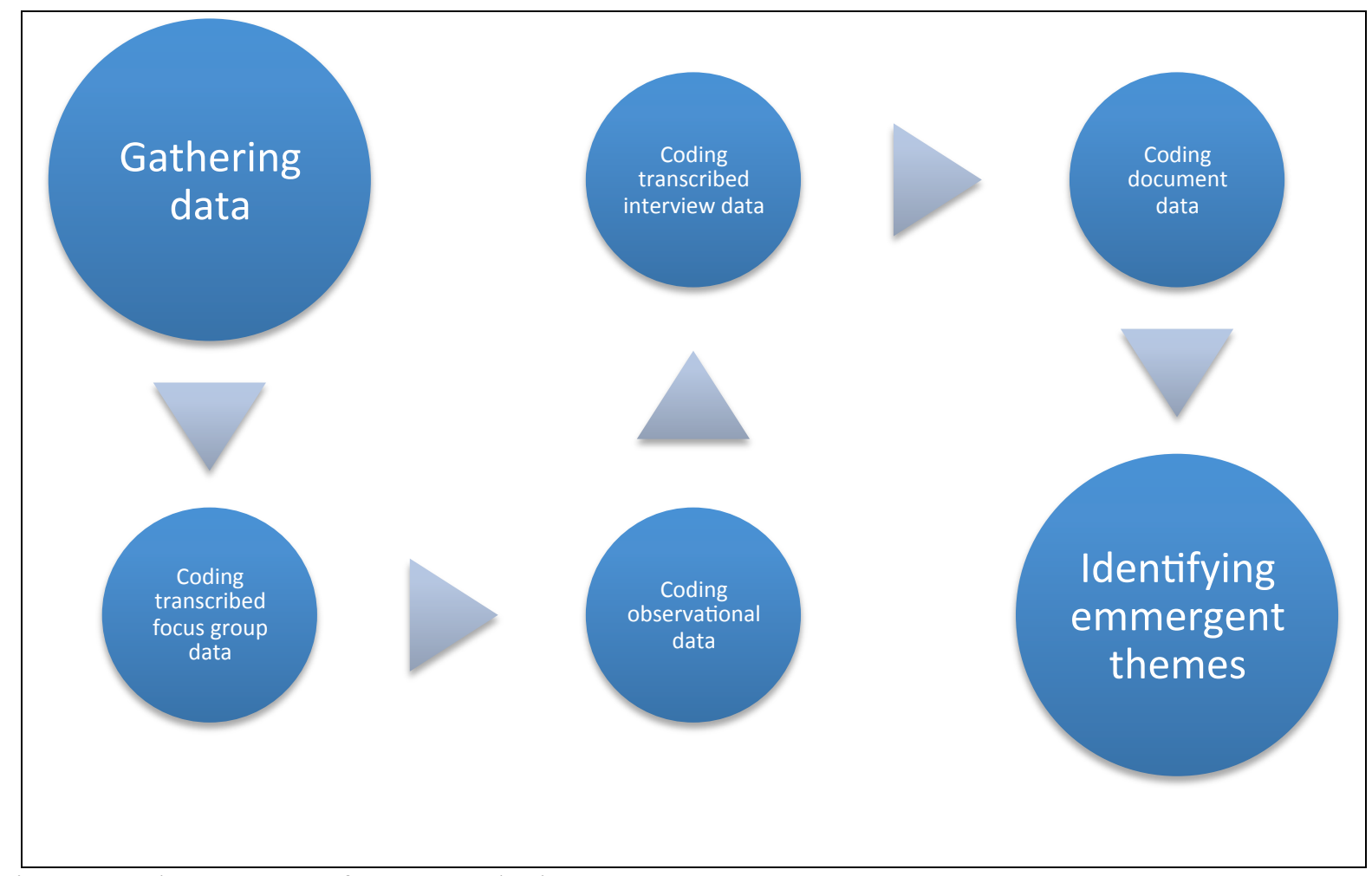

Figure 1: The Process of Data Analysis 


\section{The Setting}

The research took place in a large suburban school district in northwestern Missouri. The district serves approximately 18,500 students in kindergarten through grade 12 . The researcher gathered data from the counseling departments of the four high schools. For the purpose of this project the high schools were assigned the pseudonyms North High School, South High School, East High School, and West High School.

North High School has a population of 1,422 students. Of those students $19.1 \%$ qualify for free or reduced lunch. Data based on the graduating class of 2014 indicated in preparation for college or university study, 252 seniors took a national standardized college admissions tests and 35 students participated in a college preparatory honors program. With a $97.98 \%$ graduation rate, North High School had a college or university enrollment rate of $79.9 \%$ by the fall of 2014 .

South High School has a population of 1,555 students. Of those students 54\% qualify for free or reduced lunch. Data based on the graduating class of 2014 indicated in preparation for college or university study, 188 seniors took a national standardized college admissions tests and 60 students participated in a college preparatory honors program. With a $92.4 \%$ graduation rate, South High School had a college or university enrollment rate of $61.9 \%$ by the fall of 2014 .

East High School has a population of 1,298 students. Of those students $54.9 \%$ qualify for free or reduced lunch. Data based on the graduating class of 2014 indicated in preparation for college or university study, 188 seniors took a national standardized college admissions tests and 20 students participated in a college preparatory honors program. With a $94.23 \%$ graduation rate, East High School had a college or university enrollment rate of 58.1\% by the fall of 2014 . 
West High School has a population of 1,404 students. Of those students $43.1 \%$ qualify for free or reduced lunch. Data based on the graduating class of 2014 indicated in preparation for college or university study, 223 seniors took a national standardized college admissions tests and 25 students participated in a college preparatory honors program. With a $91.58 \%$ graduation rate, West High School had a college or university enrollment rate of $64.2 \%$ by the fall of 2014 .

\section{Participants}

The participants in the study are high school counselors and other student services personnel who work with students on the process of gaining access to college. In the initial design of the project, the participants were identified as high school guidance counselors. However, initial contact indicated that others assist with this process at several schools. Therefore, when possible, others participated in the interviews, focus groups, and observations. The chart below indicates the focus group participants by pseudonym in the study.

\begin{tabular}{|c|c|c|c|c|}
\hline $\begin{array}{c}\text { Participant job } \\
\text { title }\end{array}$ & $\begin{array}{c}\text { North High } \\
\text { School }\end{array}$ & $\begin{array}{c}\text { South High } \\
\text { School }\end{array}$ & $\begin{array}{c}\text { East High } \\
\text { School }\end{array}$ & $\begin{array}{c}\text { West High } \\
\text { School }\end{array}$ \\
\hline Counselor & N-A & S-A & E-A & W-A \\
\hline Counselor & N-B & S-B & E-B & W-B \\
\hline Counselor & N-C & S-C & E-C & W-C \\
\hline Counselor & N-D & S-D & E-D & \\
\hline $\begin{array}{c}\text { Gifted Resource } \\
\text { Teacher }\end{array}$ & N-E & S-E & E-E & W-D \\
\hline $\begin{array}{c}\text { College Adviser } \\
\text { College Adviser }\end{array}$ & S-F & & \\
\hline
\end{tabular}

Figure 2: Participants: Individual participants are identified with two letters. The first letter indicates their school; the second identifies each individually. 
Themes

Throughout the process of data analysis, the researcher became acutely aware that the participants in this study have limited knowledge about assisting undocumented students as they attempt to gain access to college. In spite of having plans in place and goals to help students throughout the district prepare for a successful transition to post-secondary opportunities, there is little evidence of specific information for undocumented students.

For example, in the district-wide document 2014-2015 Program of Studies for Course and Career Paths Guide, the superintendent opens his annual letter with the words, "we also want to prepare students for success after high school. We do this by setting high expectations and offering numerous avenues for students to achieve their unique potential” (p. 6). Additionally, the guide contains information about college admissions tests (ACT and SAT), eligibility requirements for college-level athletics, and preparing for college level work by planning a high school path with that end goal in mind. The guide does not, however, mention college access for undocumented students. The section titled "Preparing for Post-Secondary Choices: A+ Schools Program," does include a mention of the Free Application of Federal Student Aid (FAFSA). Students who meet A+ requirements during high school are eligible for financial incentives at Missouri's community colleges to cover costs of tuition and general fees. However, "failure to complete the FAFSA will result in denial of A+ benefits." While it may not be obvious to all readers, this statement does eliminate undocumented students from receiving A+ benefits.

Thus three recurring themes became evident to the researcher throughout the data analysis process. There is a lack of awareness, a lack of knowledge, and a lack of training for 
high school guidance counselors in Missouri as they assist undocumented students with access to college.

Lack of Awareness

While each of the counseling departments had some awareness about undocumented students attending their high schools, there was general agreement that identifying those students is difficult. It starts with confusion about whether or not high school counselors are allowed to ask if students are documented or not. On enrollment documents students are asked to provide information concerning racial/ethnic heritage, ethnicity, race, first language, and country of origin. Additionally there is a space to provide a social security number. However, there is no proof of citizenship required and providing the social security number is optional. Opinions, however, differ from school to school about whether or not high school counselors can ask a student directly about the immigration status of his or her family.

Based on an experience from another school in another district, counselor NC believes that he should not ask. "I asked the question that I wasn't supposed to ask," he said. "So now, every time I kind of steer away. I shy away from those terms because I don't want to get myself in trouble." He went on to explain that his intentions when he originally asked were pure. "I'm not trying to be nosey. I'm just trying to help." Counselor SB, from South High School expressed similar sentiments, "It's not legal for us to ask if they are documented or not. We find if they are not based on their relationship with us, and the trust level."

Counselor WA from West High School had the complete opposite approach. She explained that if she saw some indicators that raised her suspicions, she might be willing to be quite direct in order to know if a student has documentation or not. There are "going to be some 
indicators where you might come out and, 'Is your family documented?' And then they'll talk to you if they know you're a safe person." One of her colleagues, WC seemed less confident about asking a student in such a straightforward manner, "It's a hard question to ask," and "I didn't know it was even legal to ask them. But maybe as a counselor we can." Other counselors agreed that by asking the question they would be violating the student's privacy and or risking the student and the student's family's safety. WC vocalized this concern, "To have their name out is very risky; they're at risk of being deported." Counselor WA, however, disagreed. "I always feel like we can ask anything as long as we let them know it's in confidence."

While documents would indicate the counseling department throughout the school district has a chain of command starting with a Director of College and Career Readiness and progressing down to the high schools through a Lead High School Counselor and individual school Department Chairs, neither the focus groups nor individual interviews revealed agreement about whether or not high school counselors and others working with students on the college application process have the legal authority or right to question a student about his or her immigration status.

The disagreement about whether or not high school counselors can even ask about a student's immigration status leads in to another issue based on lack of awareness: Who are the students in each high school that might have undocumented status? Some of the departments demonstrated a strong consensus indicating they expected the Hispanic population would be the most likely to have students without documentation. Throughout the focus group conversation, participant WD made multiple references to organizations that offer specific help to Hispanic immigrants including the Guadalupe Center, the Don Bosco Center, and the Mexican Consulate. 
Additionally, several participants assumed their English Language Learner (ELL) population would comprise many of their undocumented students. When considering the North High School's population, NB and NE were in agreement that undocumented students had either "initially" been ELL students or "they might be good friends" with ELL students even "if they are not actually receiving services." Counselor WA corroborated that idea and suggested that as counselors they tend "to go by some stereotype - they're Hispanic, maybe they've been in ELL, that tends to be where our undocumenteds come from."

Counselor SB from South High School, however, whose caseload includes all ELL students in the building, had a different perception. "I think the majority of my undocumented students, those students who do not have a work permit or legal residency in the U.S., are those who do not qualify for ELL." She continued to explain that point of view because many ELL students are also refugees from war-torn countries. "Very few ELL students are what I would consider undocumented." Meaning that, as refugees fleeing violence, discrimination, and ostracism in their homeland, the many ELL students in her school have found a safe haven in the United States and have proper paperwork.

A final lack of awareness counselors expressed was a lack of awareness concerns the secrecy surrounding the issue of undocumented students. Across the district, counselors consistently expressed frustration about helping undocumented students because the students remain hidden. In spite of the questions about whether or not counselors can ask "the question" as $\mathrm{NC}$ put it, most counselors were in agreement that a main reason they cannot do effective college advising with undocumented students is because they do not know who the undocumented students are on their caseloads. 
Each of the high school counseling departments discussed their processes and procedures for helping all students through the college decision-making process. North High School's NC described multiple programming components to help students through the college-going process. "The counseling website walks them through that process. There's even a step by step college application on there." WC described individual meetings counselors at West High School have with all seniors. "Our department developed a checklist, I mean a time line, throughout the calendar year of what things they should do as far as the application process, FAFSA and those things." He went on to say, however, “I don't know who my undocumented students are. I don't have kids or parents telling me." Others, however, expressed that in those individual meetings is sometimes when students will disclose their status. Counselor SA from South High School expressed frustration about undocumented students who "fly under the radar" in her story about Kim (pseudonym).

I had a student I worked with for four years and I didn't know. She was Asian descent and her family had moved to Germany and lived there some years before they came here. She never told me, and I just assumed they were legal. Finally her senior year when we were trying to get down to the nitty gritty of planning to finish her four-year plan, she said with a lot of embarrassment, "I'm, we're, not here legally.

Counselor WA recounted a similar story of a young woman,

She was so talented, but she never did get to go [to college]. She was as American as anybody you would ever talk to. She didn't have an accent and didn't even know how to speak her own language. Her parents really wanted to Americanize her. She was really, really talented, but can't reach her potential.

And while these are just two examples of how undocumented students hide in plain sight for years, the problem is widespread. Counselors across the district suggested the main reason for the culture of secrecy surrounding the issue is fear. SA lamented the experience above, "The kids are afraid, you know, maybe to get their family in trouble." 
It is not just the high school guidance counselors who lack awareness about undocumented students. Sometimes the students themselves are confused. Counselor SB recounted the story of a young man who believed he was illegal, but who actually was not. He was born in Central America, but his mother, from whom he was estranged, was born in Puerto Rico. He did not realize that as a territory of the United States, Puerto Ricans are granted citizenship in the United States. Thus as a child of a citizen, he was also a citizen. "His entire 20 years, he has lived under the belief that he is here illegally," SB explained.

Other participants expressed a lack of awareness is the opposite direction. Counselor NB and NE both discussed the possibility that parents might shield their children from the truth as a means of protection. NB described this possible scenario, "I would think that the students may not know they are documented or undocumented. Even if you ask them the question ... they might not know the answer to it." By hiding the truth about their family's immigration status, parents avoid the risk of students accidently revealing their secret.

Other issues arise when the child does have citizenship and one or more of the parents do not. Counselor WB described an experience with a student who was born in the United States, therefore he was a legal citizen, but whose father was undocumented. For years the father had used his son's social security number to file income taxes and borrow money. "When he started to negotiate college, it became a real issue because his social security card had debt tied to it." Additionally, students who are citizens can apply for federal financial aid, but they cannot use their parents' income information. Therefore they must declare themselves as an independent student. This can be quite difficult for students who are younger than 23. In order to be considered independent, a student must be married, served in the military, have been orphaned or a ward of the state, have been declared an emancipated minor or unaccompanied homeless youth 
(When I Fill Out the FAFSA Am I Dependent or Independent, 2014). While filing the Free Application for Federal Student Aid as an independent student might be an option for some students, most who have undocumented parents will not have that as an option.

\section{Lack of Knowledge}

The second theme that emerged through the data analysis is that there is a lack of knowledge especially when it comes to the legal aspects of how to work with undocumented students. Although the four high school counseling departments were in agreement that as a part of a public school, they did have the responsibility to provide an education to all students regardless of their immigration status, there was confusion about what federal law allows when students graduate from high school and are ready to enter a post-secondary institution. Across the district a general lack of knowledge concerning federal and state law was wide spread.

\section{Lack of Knowledge Concerning DREAM Act}

When asked what they knew about federal law concerning undocumented students North High School used humor to deflect the question. Answers included, "Can I google that?" (NE). or "Can I phone a friend?" (ND). In spite of the fact the DREAM Act remains in the news regularly, no one at this high school could name or articulate any substantial meaning concerning it. The other three high schools had more awareness about federal laws, but a complete or accurate understanding was present nowhere.

For example West High School counselors could talk about federal money and having knowledge that undocumented students do not have access to those dollars. WA mentioned that a lot of times students will start talking about their immigration status and trying to get help when "they start to realize the they have to pay cash" to attend college or vocational training. WD 
added that she knows of an athlete who is "only looking at schools that are giving him complete scholarships because he knows he cannot get any federal money." The social security number seems to be the talisman for West High School counselors as they advise undocumented students. "They have to have a social security for FAFSA and they have to file FAFSA even for A+," said WD.

South High School counselors continued to express a lack of knowledge about federal law pertaining to undocumented students. "I don't feel like I have a very good understanding. I have this kind of ambiguous understanding that there is a DREAM Act out there somewhere that could help some of our students, “ commented SA. Another participant, SE, because of her lack of knowledge simply stated, "I tend to recommend them to a local college who works with undocumented students, and I kind of pass the buck." Additionally, no one in this group shared an accurate concept of the DREAM Act or deferred action. Participant SF was confused about the DREAM Act in Missouri. "Now they (undocumented students) are eligible for in-state tuition and scholarships," she stated. Additionally, although several counselors at South High School had heard about Deferred Action none of them knew what it was or how students could access the benefits available to them if they qualified for deferred action.

Finally East High School showed a similar lack of knowledge concerning federal law and undocumented students. There was a sense that undocumented students had limited access to federal money. EA recalled a student athlete who had potential for scholarship money, but his lack of documentation was a factor. "I don't think they necessarily knew right up front, but that's when things had to stop. Because I just don't think they can provide the money without documentation," she explained. EB discussed work she had done in a previous district concerning students who entered high school and needed modified graduation plans. "We 
worked with them to get them graduated on time." She went on, however, to say that she did not know much about federal law and the college admissions process for undocumented students, "I have the impression that it's kind of up to each university as to how they handle it."

A lack of knowledge about federal laws pertaining to undocumented students exists throughout the district. Because of this lack of knowledge, counselors and other student services professionals who assist with the college-going process struggle to understand what they are and are not allowed to do with and for undocumented students and their families throughout the college application process. As such many expressed frustration. "I see all of the international students that get to come here and experience our education system, and then we have our own [international students] that have been brought up in our education system, and the door is closed to them," said EA. "The law varies so drastically from state to state," said SE. "Does it just relate to that state? Does it just relate to that circumstance? And what is the liability issue? Are we mandated reporters? If we are, we are all going to jail." SA continued that discussion, "I don't know what I can or can't do to help a kid legally, but there's also the frustration on a personal level. It just feels like this roadblock dead end. I don't know how to help."

\section{Lack of Knowledge Concerning Deferred Action for Childhood Arrivals}

Two of the four high school counseling departments discussed the term Deferred Action. Participant SF could not recall the name of the program, but she was vaguely aware of sketchy details concerning Deferred Action for Childhood Arrivals. "I don't know if it's a law or an act ... but students are able to go to school that have stayed in the United States for a certain period of time," she mentioned. West High School has one person who knew a bit more about Deferred Action because of a family connection to a law firm that assists families with the 
process, but her knowledge about it was limited as well. "It's really expensive for them to get Deferred Action... [and] the beauty of that is when President Obama put that in place, he guaranteed them an application for Deferred Action cannot [result] in being deported."

Deferred Action for Childhood Arrivals is actually a policy put in place by the Department of Homeland Security under the direction of President Barack Obama. Its purpose is two-fold. First, it allows the Department of Homeland Security to focus on the deportation of undocumented residents who "pose a danger to national security or a risk to public safety" (Deferred Action For Childhood Arrivals, 2014). Second, it allows a delay in deportation procedures for individuals who are not a threat. Individuals may apply for deferred action if they meet specific criteria. One provision for eligibility is if the person is enrolled in school. Therefore, undocumented students, who meet the other qualifying guidelines, can apply for Deferred Action and any attempt at deportation will be delayed for at least two years. While Deferred Action for Childhood Arrivals does not provide a pathway for citizenship in the United States, the status can be renewed at the end of two years and it could lead to eligibility for employment authorization.

The counselors in the study indicate some awareness of what one purpose of Deferred Action is, but they have limited knowledge about how to advise students who might want to pursue a classification under Deferred Action protections other than to advise them to seek advice from an attorney or community organizations that are willing to help families through that process. None of the counseling departments in study had a plan in place to refer undocumented students and their families to organizations or attorneys with expertise in Deferred Action. Most of the counseling departments could not even name an organization that could help with the process. 


\section{Lack of Training}

Thus the lack of awareness and the lack of knowledge lead to the heart of the issue, which is a lack of training. The counselors in this school district have not received any districtlevel training on how to assist with undocumented students. As such they depend on other individuals or organizations to assist them as they work with undocumented students going through the college application process.

Three of the four high school counseling departments consider their ELL teachers a main resource when it comes to assisting undocumented students with the college application process. North High School shared consensus that their ELL teacher would be their first resource. According to NC, "We consider her our expert. We are all comfortable with her knowledge and what her process is. We all kind of lean on her actually." Participant NA agreed, "I think she is so well known among the students ... they automatically seek her out." She went on to say that she sees a network that exists among the students. When students learn of an undocumented student, they will say, "Go to Mrs. Smith (pseudonym). She'll help you.” Counselors at East High School also named their ELL teacher as the person they often turn to with questions concerning undocumented students. In describing an undocumented student who had been trying to get a job last year, Counselor ED relied on the ELL teacher as a person she could turn to who would know what to do and how to help.

Another common resource for high school counselors assisting undocumented students is local colleges. SC said, "I think if it weren't for those two local colleges that I have gotten to know that accept undocumented students or work with undocumented students, I am not sure I would know what to do." EB expressed similar feelings. "We would work very closely with the 
local university because, I mean, it is ultimately going to be up to them as to what they can or cannot do." NE mentioned a conference some counselors in the district attended in the fall where college admissions counselors from around the state of Missouri were given time to highlight some aspects of their institutions. "Several of the college admissions reps [said] 'Go ahead and send us your undocumented students.' They were evidently acknowledging them." Confirming the confidence counselors have in the local colleges, SC said, "I feel like if they work with the local colleges, they know what they are doing. And they will take care of them."

Finally concerning training, the participants in the study were quite vocal about what they thought they needed. The idea of a cheat sheet or guide for counselors came up at all four high schools, both in focus groups and in individual interviews. "There needs to be a help guide for counselors to say 'Here's the nitty gritty, what you need to know," said NC. "What we can and can't help them with. Where we can steer them," continued NB. At West High School, WB complained, "We've had no formal training at all." Additionally, when they have had guests attend meetings to offer some help, the information is not always good information. WD described a time when a speaker from the Full Employment Council presented to the group. "What he provided wasn't accurate. They had to send out a disclaimer." She continued. "What we need is a fact sheet: This is an option for you. Here are some resources you could use." The request for a guide was reiterated from both South and East High Schools. SA asked, "Is there a federal or state guideline that we could have as a cheat sheet or a handout that we could provide for the student and their family?" ED echoed that point, "Just a step-by-step process. I want to be able to guide them, so some type of cheat sheet of how to get in and if federal funds aren't available, then is there a private foundation that can maybe help support." 
Utilizing resources both inside and outside the school community is a common practice among this district's counselors as they attempt to help undocumented gain access to college and other post-secondary opportunities. At this point their training is non-existent at worst, sporadic at best. High school guidance counselors access information from those who may have more experience and or expertise and they rely on college admissions offices who are willing to work with undocumented students. However, they have a strong desire for additional, more formalized training along with a document to guide their practice.

\section{Summary}

Throughout Chapter Four the researcher provided the presentation and analysis of the data. This chapter was divided into nine sections covering the following topics: (a) a description of the study design, (b) a description of the data collection methods utilized, (c) a recap of the conceptual underpinnings, (d) a restatement of the research questions, (e) a description of the process of data analysis (f) a description of data collection methods, (g) a description of the setting, (h) a description of the participants, (i) and a discussion of the three emergent themes which include a lack of awareness, lack of knowledge, and lack of training

Chapter Five will include a summary of the findings, the limitations of the study, and the implications for future research. The summary of findings will explore the affects of high school guidance counselors lacking awareness, knowledge, and training concerning undocumented students attempting to gain access to college. The limitations of the study will examine how the nature qualitative research in general and a case study in particular makes generalizing the data difficult. Finally, the researcher will discuss the implications this research will have for future research and for future training and practice of high school guidance counselors. 


\title{
CHAPTER FIVE
}

\section{SUMMARY, RECOMMENDATIONS, AND CONCLUSIONS}

\author{
Introduction
}

This case study explored the knowledge high school guidance counselors in Missouri have when assisting undocumented students trying to gain access to college or other postsecondary opportunities. The researcher utilized the tools of case study including document analysis, individual interviews, focus groups, and observations (Merriam, 1998) in order to answer two main research questions: What knowledge do high school guidance counselors in Missouri have when assisting undocumented students attempting to gain access to college? And what knowledge do high school counselors in Missouri lack when assisting undocumented students gain access to college? The gathered data was analyzed using a systematic process for qualitative research (Creswell, 2003).

The documents were gathered, coded, and analyzed with particular attention given to information concerning college admissions, college readiness, and immigration status. The interviews were recorded and transcribed and the transcriptions were returned to the individual subject in order to allow for member checking which is essential for a clear understanding about the interviewee's meaning (Merriam, 1998). Additionally the focus group discussions were recorded and transcribed. The transcriptions of the interviews and focus groups where then analyzed and coded. Finally the researcher attended three presentations on college admissions at two different high schools and took detailed field notes. After all the data was coded, the researcher began looking for themes. Merriam says, "Coding occurs at two level - identifying information about the data and interpretive constructs related to analysis (1998). Throughout the 
process of gathering data through documents, focus groups, interviews, and observations, the researcher continuously reviewed the data identifying information and interpreting meaning. According to Krueger and Casey (2000), "Doing analysis as you go improves the data collection" (p.129). This process allowed the researcher to refine conversations during interviews and focus group discussions and seek additional documents throughout the data analysis phase.

After much consideration, three themes emerged from this study. Initially the researcher expected the participants to have more experience with undocumented students attempting to gain access to college. However, based on the documents, focus groups, interviews, and observations, the high school guidance counselors participating in this study expressed a lack of awareness, a lack of knowledge, and a lack of training when it comes to assisting undocumented students through the college admissions process. Furthermore, the district in this study currently does not have clear guidelines for high school counselors to follow when assisting undocumented students attempting to gain access to college.

Chapter Five will offer a summary of findings, conclusions, limitations, and implications for future practice. The summary of findings will explore the affects of high school guidance counselors lacking awareness, knowledge, and training concerning undocumented students attempting to gain access to college. The limitations of the study will examine how the nature qualitative research in general and a case study in particular makes generalizing the data difficult. Finally, the researcher will discuss the implications this research will have for future research and for future training and practice of high school guidance counselors. 


\section{Summary of Findings}

The purpose of this study was to explore the knowledge of high school guidance counselors in Missouri as they assist undocumented students attempting to gain access to college. The study was viewed through the lenses of Critical Race Theory (CRT), Latino Critical Theory (LatCrit), and Social Capital Theory. Most of the undocumented students in the United State are non-white and up to 78\% come from Mexico or other Latin American countries (Gildersleeve, Rumann, \& Mondragon, 2010). Delgado and Stefancic (2001) argue racism is difficult to address because society tends to overlook everyday acts of racism that are built in to social systems, including education. Society at large, and high school guidance counselors in particular, would be outraged if an institution of higher education publicly proclaimed that non-white, non-citizens were not allowed to enroll or attend. Yet for many undocumented the results of reality and this example are the same - limited access.

Additionally, undocumented students do not fit neatly into a single category. Multiple factors intersect including, race, gender, class, national origin, and sexual orientation (Delgado \& Stefancic, 2001). Most undocumented students find themselves identifying as having at least "triple minority status" which includes their ethnic origin, lack of documentation, and economic disadvantages (Perez, Cortes, Ramos, \& Coronado, 2010), however, the number of groups to which an individual could potentially belong is immeasurable when you consider such minority groupings as English language learner, gay, lesbian, bisexual, trans-gendered, female, non-white, etc. The college advising needs for undocumented students, therefore, depend on multiple factors. Proficient high school guidance counselors strive to meet the individual advising needs of the students assigned to them (American School Counselor Association, 2013). 
The two guiding questions the researcher hoped to answer through this study were:

1. What knowledge do high school guidance counselors in Missouri have to assist undocumented students attempting to gain access to college?

2. What knowledge do high school counselors in Missouri lack to assist undocumented students attempting to gain access to college?

Throughout the study the answer to the first question became obvious - very little. In fact among the four high school counseling departments participating in the study, the only common piece of knowledge was the fact that undocumented students cannot apply for and receive federal financial aid. From this study, the researcher identified three themes: there is a lack of awareness, a lack of knowledge, and a lack of training among high school counselors in Missouri attempting to assist undocumented students gain access to college.

\section{Lack of Awareness}

The participants in the study lack awareness about who the undocumented students in their school are, how to identify the undocumented students in their school, and how to break the code of secrecy among undocumented students in their school. Because of this lack of awareness, the high school guidance counselors and others who help students with college access struggle with first steps in order to assist undocumented students.

Undocumented students do not typically advertise their immigration status. Students and families cannot be required to reveal their status upon enrolling in school. The Supreme Court confirmed that children of undocumented immigrants have the right to seek a public K-12 education in the landmark decision Plyler v. Doe (Gildersleeve, Rumann, \& Mondragon, 2010; Drachman, 2006). Therefore, families are not required to prove citizenship or immigration status when enrolling. As a result, it is difficult for school personnel, including high school guidance 
counselors, to identify undocumented students who might need additional services while going through the college search and application process.

Federal law does not expressly forbid school employees from directly asking students about their immigration status, and the district in this study does not have board policy expressly restricting employees, including high school guidance counselors, from asking students about their immigration status. It is, however, common practice throughout the district for high school counselors and others to avoid asking students questions concerning their status. As result, the high school counselors tend to discover a student's immigration status by chance. Often only if undocumented students have a trusting, working relationship with a counselor, have a strong desire to seek post-secondary educational opportunities, and are willing to risk exposure will they reveal their undocumented status. Many times this revelation comes late in the collegeseeking process and counselors struggle to find avenues to help them with admissions, acceptance, and financial assistance.

While the high school guidance counselors in this study struggle to know who the undocumented students are, they do try to identify them. Often times their identification methods tend to reinforce stereotypes. For example, three of the four schools agree they would most likely find undocumented students among their English Language Learner (ELL) population or their Hispanic population. While undocumented students can and do exist within these populations, they commonly exist outside them as well. For example, students who would qualify for Deferred Action for Childhood Arrivals, have been in the United States since they were very young. As such, their academic language is no longer their mother tongue, but English. As a result they would no longer be receiving ELL services. 
Another clue high school guidance counselors in the study consider a typical signal that a student might be undocumented occurs when an accomplished academician balks at applying for college. Students who are non-white and non-native and have done well in school, but then appear to settle for a post-high school plan that does not include college, would likely prompt high school guidance counselors to look for reasons why. In fact two counselors in the study indicated this was the reason they had been willing to ask about immigration status in the past, because they felt compelled to help these students find a pathway to college and beyond.

Finally a compounding factor that surrounds all aspects of awareness is a code of secrecy: Students and families who are afraid to tell anyone about their immigration status out of fear they will be deported; high school counselors and other school personnel who are afraid to ask questions because they do not want to be offensive or put the student and family at risk. All of this secrecy makes assisting undocumented students who are attempting to gain access to college feel like an underground activity.

\section{Lack of Knowledge}

Throughout the study, the researcher discovered that the lack of knowledge has a direct affect on the practice of high school guidance counselors attempting to assist undocumented students attempting to gain access to college. The high school counselor participants in the study expressed frustration with a general lack of knowledge about federal law and the DREAM Act. Additionally they discussed vague perceptions of Deferred Action for Childhood Arrivals, but had very little knowledge about how it could be used to assist the undocumented students they might assist in the college-going process. 
Undocumented students are not eligible to receive federal money to help finance their post-secondary education, both the Illegal Immigration Reform and Immigrant Responsibility Act of 1996 and the Personal Responsibility and Work Opportunity Reconciliation Act of 1996 make this clear (Gildersleeve, Rumann, \& Mondragon, 2010; Drachman, 2006). However, federal law has not dictated many other aspects of college-going for undocumented students. For example, there is no federal law dictating whether undocumented students should pay resident or non-resident tuition rates at public institutions. As such, states have made those decisions themselves. The introduction of the Development, Relief, and Education for Alien Minors (DREAM) Act was meant to clarify some those discrepancies among states by clarifying offering in-state resident tuition to undocumented students and to provide an eventual pathway for citizenship (Gildersleeve, Rumann, \& Mondragon, 2010).

The researcher discovered the participants in the study had very little knowledge about the DREAM Act. None of the counselors were able to articulate that the DREAM Act is not the law of the nation, nor could they say whether or not it was the law in Missouri. Additionally, they were unclear as to its purpose and how it could benefit their undocumented students.

Additionally, two of the counseling departments were able to mention Deferred Action for Childhood Arrivals during the focus group discussions. However none of the high school guidance counselors or other personnel could articulate its purpose - which is to allow people who entered the United States illegally as children to delay the process of deportation if they are attending school or in the military (Deferred Action for Childhood Arrivals, 2014). As such the participants were unable to discuss how they would utilize Deferred Action as a method for helping undocumented students other than to refer them to lawyers or community organizations that could assist with the process. Additionally, because of a lack of knowledge and 
understanding about Deferred Action, several participants seemed reluctant to pursue this avenue as a means to help students out of fear it would put them at risk for discovery and the potential of deportation. None of the counseling departments had a plan in place to refer undocumented to experts to specific organizations or individuals who might what to seek protection under the Deferred Action policy.

\section{Lack of Training}

Throughout this study, it became apparent that the lack of awareness and lack of knowledge was a direct result of a lack of training. The high school guidance counselors demonstrated a strong commitment and desire to help all of their students, including their undocumented students, reach their potential. Their passion was obvious as they told individual stories of undocumented students who had either somehow managed to navigate the process to enroll in college, or who had been unsuccessful and were unable to live up the potential they had demonstrated as high school students.

The high school guidance counselor participants who did have direct experience helping undocumented students, discussed training that was reactive rather than proactive. Whenever faced with a situation with an undocumented student attempting to gain access to college, the common response was to look for resources to could help. Those resources included English Language Learner (ELL) teachers and college admissions personnel who have a reputation for working with families of undocumented students. There was an overwhelming desire from the participants for district-level training and resources that could help them know what do in order to better serve their undocumented students. 
Thus the next question becomes: Why isn't there training for high school guidance counselors in Missouri to assist undocumented students attempting to gain access to college? For the district in this study, the answer seems to be circular in nature; there is a lack of awareness that there is a lack of knowledge and a lack of training.

Considering this problem through the Critical Race Theory (CRT) lens and the Latino Critical Theory (LatCrit) lens, the researcher could jump to the conclusion that this is just another example of the educational establishment allowing non-white, non-native students to navigate a system on their own without a support system in place. In fact, CRT forces educators to look at the educational experiences from the perspective of communities of color and recognize the oppressive practices that have long existed. In an effort to remain colorblind and reward based on merit, as many educational organizations do, without considering the oppression people of color face, educational systems ignore needs specific to students of color (Perez Huber, 2010). And while racist nativism is often considered an historical black mark from our nation's past, the fact is, undocumented students in the United States continue to face persecution and humiliation, and they remain helpless to do anything about it (Perez, Cortes, Ramos, \& Coronado, 2010).

With this in mind, however, it is essential to consider the principles high school guidance counselors hold most dear. The American School Counselor Association identifies school counselor competencies aimed at insuring adequate post-secondary preparation for all students regardless of race, disability, socio-economic background, religion, sexual orientation, or any other category students fall into. This would include students who do not have legal documentation to reside in the United States. Consider the list of competencies from section I-C: Attitudes: 
I-C-1. Every student can learn, and every student can succeed

I-C-2. Every student should have access to and opportunity for a high-quality education

I-C-3. Every student should graduate from high school and be prepared for employment or college and other post secondary education (American School Counselor Association, 2013).

The high school guidance counselor participants in this study live by this list of competencies every day in their work with all types of students. As such, there is a strong desire among them to do the necessary work to help undocumented students gain access to college. Furthermore, high school guidance counselors often take on the role of advocate for their students (American School Counselor Association, 2013). Throughout this study, the participants did more than mention a lack of training. They requested training and materials that could help them navigate this process with their undocumented students in a more proactive rather than reactive way.

\section{Conclusions}

The purpose of this study was to explore the knowledge of high school guidance counselors in Missouri as they assist undocumented students attempting to gain access to college. The exploratory nature of case study allows researchers to gain an in-depth understanding about the details of a program (Merriam, 1998). Additionally qualitative data tell a story filled with rich description. Qualitative researchers are able to share the unique stories of others in their own words (Patton, 2002). Utilizing the tools of case study, as identified by Merriam, including document analysis, individual interviews, observations, and focus groups, the researcher discovered three emergent themes while exploring the knowledge high school guidance counselors in Missouri have when assisting undocumented students attempting to gain access to college. These three themes were a lack of awareness, a lack of knowledge, and a lack of training for high school guidance counselors in Missouri assisting undocumented students attempting to 
gain access to college. These gaps in awareness, knowledge, and training seem to feed upon each other. As illustrated in Figure 2, no matter what the starting point is, it leads to another gap in either direction: because there is a lack of awareness, there is a lack of knowledge; because there is a lack of knowledge, there is a lack of training; because there is a lack of training, there is a lack of awareness; because of a lack of awareness there is a lack of training; because of a lack of training there is a lack of knowledge; because of the lack of knowledge, there is a lack of awareness. It is a never-ending number of gaps where the cause becomes the effect and the effect becomes the cause that hinder the work high school guidance counselors do as they assist undocumented students attempting to gain access to college.

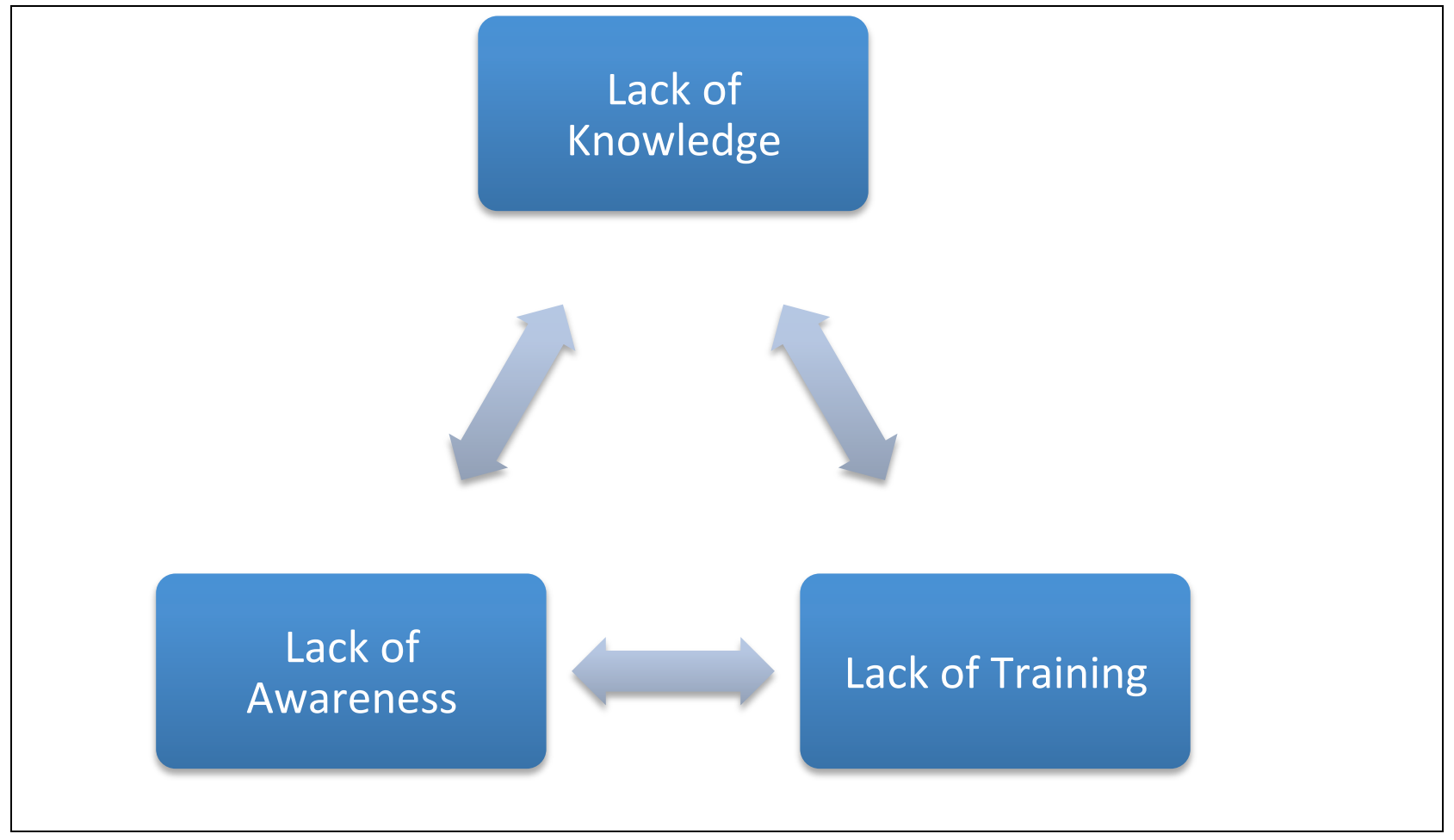

Figure 3: The Infinite Circle of Gaps that Hinder High School Guidance Counselors Assisting Undocumented Students Attempting to Gain Access to College. 


\section{Limitations}

Merriam cautions qualitative researchers to avoid oversimplification and exaggeration that could lead to erroneous conclusions. Additionally, a case study, with a generally small sample size does not always allow for results that are generalizable to a larger population. However, researchers are not always interested in broader applications, but rather the depth of the story (1998).

The tools of case study the researcher used including document analysis, interviews, observations, and focus groups inherently create limitations of their own. Document analysis requires the researcher to gain access to documents, to understand how and why the documents came to be, and apply text specific to the institution (Patton, 2002). Additionally qualitative researchers must recognize the documents were not created with research in mind and therefore may be incomplete for such purposes (Merriam, 1998). This proved to be a problem in this study. While documents were available about school district policy, college preparation, and responsibilities and expectations of high school guidance counselors, at this point there are no documents the researcher could obtain with any reference to undocumented students and their college-going. And while this researcher concludes the lack of written policy and practice concerning undocumented students is a reflection of the themes lack of awareness, lack of knowledge, and lack of training, there could be other reasons. In addition to the lack of information about undocumented students in district documents, an examination of documents available from the Missouri Department of Elementary and Secondary Education revealed that there are few policies concerning undocumented students at the state level. At this time, undocumented students are only mentioned in reference to their ability to enroll in school with out a social security number and the need for schools to provide English Language Learner 
Services to undocumented students who may qualify for such services (Serving Undocumented ELL, 2014)

Interviews allow qualitative researchers the opportunity to access data not readily observable. They allow the researcher a chance to gain insight to another person's perspective, but only in as much as the subject will allow (Patton, 2002). While the researcher hoped to gain a better insight into the working life of high school guidance counselors assisting undocumented students attempting to gain access to college, there was an unexpected challenge. The three high school guidance counselors who participated in the individual interviews seemed embarrassed by their inability to discuss this type of work with a sense of expertise. The individual interviews were limited by the individual experience and practice each of the participants had.

The focus groups discussions provided the bulk of the data in this study. Krueger and Casey (2000) recommend that focus groups consist of five to ten people in order to facilitate easy conversation whiled still allowing for diversity. Three of the four focus groups met the size criteria, while one focus group only had four participants because two of the expected participants were out of the building during the scheduled time of the focus group. Additionally, the focus groups lacked racial and ethnic diversity. Of the 20 participants in the study, only one was a non-native speaker of English, two were people of color, and four were men. Fourteen of the participants were white women. This had the potential to create a limited perspective concerning how people of color, English Language Learners, and males navigate the collegegoing process.

Finally, the use of observation has limitations. For the purposes of this study, the researcher attended three presentations for students and families concerning preparing for 
college. One was a general presentation, one was specific to college athletes, and one was specific to students interested in a particular university. While doing observations can cause the researcher to be seen as intrusive, that was not an issue during two of the observations. At one observation, the researcher was recognized as a resource on college admissions, and called upon to answer a few questions. This caused the researcher to become a part of the presentation rather than merely an observer of the presentation. Additionally, because the presentations were relatively short, the researcher did not experience a sense of immersion in the setting.

\section{Implications for Practice}

The first, and most glaring, implication for practice is a need for increased training for high school guidance counselors in Missouri as they assist undocumented students attempting to gain access to college. As illustrated in Figure 2, the circular nature of the gaps in awareness, knowledge, and training continue to create an unending cause and effect becoming cause and effect rotation that helps no one and frustrates high school guidance counselors.

As advocates for students and for social justice, high school guidance counselors in this district are asking for training and tools in order to be better prepared to seek out undocumented students and develop plans for them to reach their educational potential. Therefore, the researcher anticipates future professional development for high school counselors to help them gain awareness and knowledge as they work with undocumented students attempting to gain access to college.

Furthermore, since the school district does have a population of undocumented students, the evidence is compelling that the district policies should contain language regarding how schools and individual school employees, including high school guidance counselors, can 
provide educational opportunities for undocumented students without putting the students or their families at risk. By clarifying the district's stance on how to serve undocumented students, high school guidance counselors will have clear directions on the questions they can ask students in confidence and how they can assist students through the college selection, application, and acceptance process.

Even though qualitative research cannot be considered generalizable to the larger population, this research project does imply the need to gather data from around the state to see if other high school guidance departments are experiencing similar gaps in awareness, knowledge, and training. To that end, future researchers could consider a quantitative study throughout the state that would include rural, urban, and suburban school districts. Additionally, training for counselors throughout the state, with specific consideration to the laws and guidelines that affect undocumented students graduating from Missouri high schools, would be an appropriate next step.

\section{Concluding Overview}

This case study explored the knowledge high school guidance counselors in Missouri have to assist undocumented students attempting to gain access to college. Based on the findings of the study, it is tempting to announce the findings are that high school guidance counselors in Missouri are practically clueless when it comes to assisting undocumented students attempting to gain access to college. That, however, is unfair to the counselors and the district who participated in this study.

Critical Race Theory and Latino Critical Thought Scholars point to the racism and nativism that exists in the system throughout society, including educational systems that oppress 
people of color and immigrants (Perez Huber 2010; Delgado \& Stefancic, 2001). Additionally, Social Capital Theory scholars claim learning and development are interdependent and culturally mediated activities (Cole, 1996; Gutierrez, 2008; Gildersleeve and Ranero, 2010). Social capital may be one of the most important factors in undocumented students gaining access to college (Gonzalez, 2010). Considering these three theoretical frameworks, high school guidance counselors need comprehensive training. Of course, they need to be able understand the laws of their state and local community, the policies and practices of their school districts, the local resources to assist families who are seeking to gain citizenship or apply for Deferred Action. In addition to these practical knowledge skills, however, high school guidance counselors also need to understand the implications of being an undocumented student, which includes multiple minority status (Perez, Cortes, Ramos, \& Coronado, 2010). Furthermore, high school guidance counselors to be trained to help undocumented students learn to highlight the cultural wealth they will potentially bring to a college campus.

Finally, high school guidance counselors must recognize the importance of their role in assisting undocumented students attempting to gain access to college. Undocumented students have college advising needs similar to minority, first generation, and low-income students. Additionally, parents of undocumented students need guidance from the school in order to understand the process (Arriola \& Murphy, 2010). Undocumented students come to rely on the people in their school who are experts in helping them navigate the college-going process. Therefore, there some crucial first steps that need to be implemented to ensure the undocumented students in Missouri receive the best possible advice from high school guidance counselors. First, it is essential for school districts to develop policies that define how educators can work within the laws of the state to help undocumented students seek advice on college-going without 
fear of exposing their family. Districts also need to provide training for high school counselors on how best to serve this population of students. Colleges and universities around the state need to publish information concerning their policies and practices for undocumented students so high school guidance counselors, undocumented students, and their families can have easy access to that information. As high school counselors begin to gain awareness about their training needs in order to better serve undocumented students, they should request workshops through the state organizations including the Missouri School Counselors Association and the Missouri Association of College Admissions Counselors. Finally, since the Missouri Department of Elementary and Secondary Education does not currently publish policies concerning undocumented students and college access, high school guidance counselors and school districts should advocate for this issue to be discussed and policies be developed and published. 


\section{References}

American School Counselor Association. (2013, June 21). Retrieved from ASCA School Counselor Competencies: http://www.schoolcounselor.org/files/SCCompetencies.pdf

Arriola, S., \& Murphy, K. (2010). Defined by limitations. Journal of College Admission, 27-28.

Bourdieu, P., \& Passeron, J. (1977). Reproduction in education, society and culture. London: Sage.

Carroll, M. R. (1985). School counseling: Dissolution or survival? NASSP Bulletin, 1-5.

Coleman, J. S. (1988). Social capital in the creation of human capital. American Journal of Sociology, S95-S120.

Crenshaw, K. (1983). Mapping the margins: Intersectionality, identity politics, and violence against women of color. Stanford Law Review. 1241-1299.

College Board. (2013, September 24). Retrieved from Guide to State Residency:

professionals.collegeboard.com/testing/international/state

Deferred Action For Childhood Arrivals. (2014, October 4). Retrieved from Department of Homeland Security: http://www.dhs.gov/deferred-action-childhood-arrivals\#2

Delgado Bernal, D. (2002). Critical race theory, Latino critical theory, and critical race-gendered epistemologies: Recognizing students of color as holders and creators of knowledge. Qualititative Inquiry, 105-126.

Delgado, R., \& Stefancic, J. (2001). Critical race theory: an introduction. New York: New York University Press.

Drachman, E. (2006). Access to higher education for undocumented students. Peace Review: A Journal of Social Justice, 91-100.

Emerson, R.M., Fretz, R.I., \& Shaw, L.L.(1995). Writing ethnographic fieldnotes. Chicago: University of Chicago Press.

Flores, S. M. (2010, Winter). State dream acts: The effect of in-state resident tuition policies and undocumented Latino students. The Review of Higher Education, 33(2), 239-283.

Gildersleeve, R. E., \& Ranero, J. J. (2010). Precollege contexts of undocumented students: Implications for student affairs professionals. New Directions for Student Services, 19-33.

Gildersleeve, R. E., Rumann, C., \& Mondragon, R. (2010, Fall). Serving undocumented students: Current law and policy. New Directions for Student Services, 131.

Gonzalez, J. \& Portillos, E.L. (2007). The undereducation and overcriminalization of U.S. Latinas/os: A post-Los Angeles riot LatCrit analysis. Educational Studies, 247-266. 
Gonzales, R. G. (2010). On the wrong side of the tracks: Understanding the effects of school structure and social capital in the educational pursuits of undocumented immigrant students. Peabody Journal of Education, 469-485.

Illinois Coalition for Immigrant and Refugee Rights. (2012). Counselor guide to resources for undocumented students.

Krueger, R. A., \& Casey, M. A. (2000). Focus groups: A practical guide for applied research. Thousand Oaks, CA: Sage.

Martinez, M., \& Klopott, S. (2003). Improving college access for minotity, low-income, and first generation students. Boston, MA: Pathways to College Network.

McDonough, P. M. (2005). Counseling and college counseling in America's high schools. NACAC.

Merriam, S. B. (1998). Qualitative research and case study applications in education. San Francisco: Jossey-Bass.

Monger, R., \& Yankay, J. (2014). U.S. legal permanent residents: 2012. Office of Immigration Statistics.

Ortiz, A. M., \& Hinojosa, A. (2010, Fall). Tenuous Options: The career development process for undocumented students. New Directions for Student Services, 131, 53-65.

Patton, M. Q. (2002). Qualitative research and evaluation methods. Thousand Oaks, CA: Sage.

Perez Huber, L. (2010). Using Latina/o critical race theory and racist nativism to explore intersectionality in the educational experiences of undocumented Chicana college students. Educational Foudation, 77-96.

Perez, W., Cortes, R. D., Ramos, K., \& Coronado, H. (2010, Fall). "Cursed and blessed": Examining the socioemotional and academic experiencesof undocumented Lantina and Latino college students. New Directions for Student Services, 131, 35-50.

Rumbaut, R. (2004). Ages, life stages, and generational cohorts: Decomposing the immigrant first and second generation in the United States. International Migration Review, 11601205.

School Counselors Contribute to College Access and Success. (2013, July 14). Retrieved from nacanet.org: http://www.nacacnet.org/issuesadvocacy/LegislativeNews/Documents/SchoolCounselorsCollegeAccess.pdf

Serving Undocumented ELL. (2014, November 30). Retrieved from http://dese.mo.gov/sites/default/files/qs-ell-serving-undocumented-ell-Rev-01-2014.pdf

Trucios-Haynes, E. (2001). Why "race matters": LatCrit theory and Latina/o racial identity. La Raza Law Journal.

U.S. Department of Education, N. C. (2004). The Condition of Education 2004 (NCES 2004077). Washington, D.C: U.S. Government Printing Office. 
When I Fill Out the FAFSA, Am I Dependent or Independent (2014, October 4). Retrieved from https://studentaid.ed.gov/sites/default/files/fafsa-dependency.pdf

Yosso, T. J. (2005). Whose culture has capital? A critical race theory discussioin of community cultural wealth. Race Ethnicity and Education, 69-91.

Zarate, M. E., \& Burciaga, R. (2010). Latinos and College Access: Trends and Future Direction. Journal of College Admissions, 24-29. 


\section{APPENDIX A}

\section{Informed Consent}

1. District-Level Permission for Counselor Participation Letter

2. Administrative Permission for Counselor Participation

\section{Letter of Informed Consent}

4. Informed Consent Form 


\section{District-Level Permission for Counselor Participation Letter}

$<$ Name of District $>$

Dear $<$ Title $><$ First Name $><$ Last Name $>$

I would like to request your permission to invite high school guidance counselors to participate in a research study entitled: The Effect of Federal Laws on the Practice of High School Guidance Counselors in Missouri as they Assist Undocumented Students Trying to Gain Access to College. I am examining how federal laws effect the way Missouri's high school counselors work with undocumented students who are trying to attend institutions of higher learning. Current federal does not prohibit undocumented students from attending post-secondary institutions, however, because Missouri is not a DREAM Act state, there are special considerations that could affect the work of high school counselors. The intention of this study is to identify knowledge gaps so that more students receive accurate information about their potential for college admission and attendance. This study is a part of my dissertation research for a doctoral degree in Education Leadership and Policy Analysis from the University of Missouri-Columbia.

For this study, I will be examining documents produced and or used by the district's high school counselors as they work with students seeking advice about college access. Additionally, I will be interviewing some individual high school counselors about their practice, conducting focus groups with high school counselors, and observing high school counselors as they present information about college access.

Participation in this study is completely voluntary. The participants may withdraw at any time they wish without penalty. Participants' answers and their buildings' identity will remain confidential, anonymous, and separate from any identifying information. The researcher will not list any names of participants, or their corresponding institutions, in this dissertation or any future publications.

Please do not hesitate to contact me with any questions or concerns about participation in this study. I can be reached by phone at $* * * * * *$ or by email at $* * * * * * *$. You may also contact my adviser for this research study, Dr. *****, who can be reached by email at $* * * * * * *$.

Thank you for your time and consideration,

Sincerely,

Martha DeVries

Doctoral Candidate 


\section{Administrative Permission for Educator Participation}

$\mathrm{I}$, , grant permission for the high school

counselors in my district to be identified and contacted if interested in participating in the study The Effect of Federal Laws on the Practice of High School Guidance Counselors in Missouri As They Assist Undocumented Students Trying to Gain Access to College conducted by Martha DeVries, doctoral candidate at the University of Missouri -Columbia.

By signing this permission form, I understand that the following safeguards are in place to protect the faculty choosing to participate:

- All participation is voluntary, and may be withdrawn at any point before culmination of the study.

- All responses will be used for dissertation research and for potential future journal publications.

- All identities and affiliations will be kept confidential in all phases of research.

- Interviews and focus group discussions will take place outside of the school day.

- Observations will take part when counselors would naturally present information about college access. This may occur during school hours, or outside of the school day.

Please keep the consent letter and copy of the signed consent form for your records. If you choose to grant permission for high school counselors in your school district to participate in this study, please complete this Administrative Permission for Educator Participation Form, seal it in the enclosed envelope and return it to Martha DeVries as soon as possible.

I have read the material above, and any questions that I have posed have been answered to my satisfaction. I grant permission for high school counselors in my district to be contacted and invited to participate in this study.

Signed: Date:

Title/Position:

School District:

Please return to Martha DeVries 


\section{Letter of Informed Consent - Counselor Participant}

[Date]

Dear (Counselor Participant)

Thank you for considering participation in a research study entitled The Effect of Federal Laws on the Practice of High School Guidance Counselors in Missouri As They Assist Undocumented Students Trying to Gain Access to College. This study is part of my dissertation research for a doctoral degree in Educational Leadership and Policy Analysis from the University of MissouriColumbia. You have been invited to participate in this study because you are a high school guidance counselor who may have or have not worked with undocumented students attempting to gain access to post-secondary educational opportunities.

The information gathered should be beneficial to other high school guidance counselors around the state of Missouri as they work with all students seeking access to post-secondary educational institutions, but particularly as they work with undocumented students.

The following questions will guide this study:

1) How does federal law affect high school guidance counselors in Missouri in their daily practice assisting undocumented students gain access to college?

2) What do high school guidance counselors in Missouri need to know in order to help undocumented students reach the point of college readiness?

3) What essential knowledge do high school guidance counselors in Missouri need in order to help undocumented students through the college decision-making and application process?

Please consider the following:

\section{Procedures}

By giving your written consent to participate in the study, you are consenting to (a) be interviewed or be a member of a focus group for a maximum of one hour, and/or (b) provide relevant documents, and/or (c) be available for follow up questions for a maximum of one hour. With your permission at the time of your interview(s) or focus group, the conversation will be audio recorded, and the recording will be kept in a secure location for seven years after it is transcribed. If you do not give permission for such recording, it will not be done. All materials related to the study will be stored in a locked file cabinet within a locked office when not in use. You may choose to receive a copy of the finished study.

\section{Risks}

There are no risks to you associated with participating in this study. 


\section{Participant Confidentiality}

Although names of individuals and agencies will be collected, they will not be used in any written reports of the findings of the study. Through use of a data coding system and pseudonyms, diligent effort will be made to preserve the anonymity of participants and agencies. Permission granted on this date to use and disclose your information remains in effect indefinitely. By signing this form you give permission for the use and disclosure of your information for purposes of this study at any time in the future.

\section{Refusal to Sign Consent and Authorization}

You are not required to sign this Consent and Authorization form and you may refuse to do so without affecting your right to any services you are receiving or may receive from the University of Missouri or to participate in any programs or events of the University of Missouri. However, if you refuse to sign, you cannot participate in this study.

\section{Cancelling This Consent and Authorization}

You may withdraw your consent to participate in this study at any time. You also have the right to cancel your permission to use and disclose further information collected about you, in writing, at any time, by sending your written request to: Martha DeVries, 3600 N Wabash Ave, Kansas City, MO 64116

\section{Questions About Participation}

Questions about procedures should be directed to the researcher(s) listed at the end of this consent form.

\section{Participant Certification:}

I have read this Consent and Authorization form. I have had the opportunity to ask, and I have received answers to, any questions I had regarding the study. I understand that if I have any additional questions about my rights as a research participant, I may contact the University of Missouri's Campus Institutional Review Board at umcresearchcirb@missouri.edu, call 573.882.9585, or write the Campus Institutional Review Board, Office of Research, University of Missouri, 483 McReynolds Hall, Columbia, MO 65211.

Sincerely,

Martha DeVries

Doctoral Candidate 


\section{INFORMED CONSENT FROM HIGH SCHOOL GUIDANCE COUNSELOR PARTICIPANTS}

I , agree to participate in the study, The

Effect of Federal Laws on the Practice of High School Guidance Counselors in Missouri As They Assist Undocumented Students Trying to Gain Access to College conducted by Martha DeVries, doctoral candidate at the University of Missouri -Columbia. I understand the following:

- My participation is voluntary and may be withdrawn at any point before culmination of the study.

- My responses will be used for dissertation research and for potential future journal publications.

- My identity and affiliation will be kept confidential in all phases of the research.

- The researcher will request a personal interview, participation in a focus, or an opportunity to observe college access presentations.

- If the need arises the researcher may be in contact either by phone or e-mail.

Please keep the consent letter and a copy of the signed consent form for your records. If you choose to participate in this study, please complete the signed consent form, seal it in the enclosed envelope and return it to Martha DeVries as soon as possible.

I have read the material above, and any questions I have posed have been answered to my satisfaction. I voluntarily agree to participate in this study.

Signed:

Date:

\section{Contact Information:}

Phone

Best time for contact E-mail: 
Appendix B

Protocol on Procedures

Protocol for Interviews

Interview Questions

Protocol for Focus Groups

Focus Group Questions 


\section{Interview Protocol}

During this interview I will be asking you ten questions about your work as a high school guidance counselor. The questions will focus on your work with students, especially students who are undocumented, who are trying to gain access to post-secondary educational opportunities.

During the interview I will be taking notes as well as recording our conversation. The audio recording with be transcribed later for the purpose of data analysis.

If at any time in the interview you decide you no longer want to participate, please let me know. Your responses will remain anonymous and you will only be indentified as Interview \#

We will begin the interview whenever you are ready. 


\section{Counselor Interview Questions}

1. Tell me about your background as a counselor including how long you have worked, where you have and currently work, and additional experiences in education.

2. Talk about your work with students who are going through the college admissions process.

3. Besides the actual application process, what other work do you do with students to help ensure they are college-ready?

4. If a student were to have the label "undocumented student" what does that mean to you?

5. How do you understand federal laws as they apply to undocumented students seeking access to college?

6. Describe one or more experience you have had with an undocumented student working through the college admissions process.

7. Discuss your knowledge, expertise, and comfort level working with undocumented students as they go through the college admissions process.

8. Discuss your lack of knowledge, expertise and comfort level working with undocumented students as they go through the college admissions process.

9. Describe the resources available to you as you assist all students in general and undocumented students in particular through the college admissions process.

10. Is there anything else you would like to discuss concerning your work with undocumented students as they go through the college admissions process? 


\section{Focus Group Protocol}

During this focus I will be asking you to discuss your work as high school guidance counselors. I have a list of guiding questions that will focus the discussion on your work with students, especially students who are undocumented, who are trying to gain access to post-secondary educational opportunities.

During the focus group discussion I will be taking notes as well as recording our conversation. My role is to guide the discussion by asking questions rather than participating in the conversation. The audio recording with be transcribed later for the purpose of data analysis.

If at any time in the focus you decide you no longer want to participate, please let me know. Your responses will remain anonymous and you will only be indentified as Participant

We will start the focus group with a brief introduction in order to differentiate voices on the audio recording.

When you all agree that you are ready to begin, we will star $t$ the discussion. 


\section{Focus Group Questions}

1. Let's begin the discussion by working our way clock way around the room. Please introduce yourself by stating your name and the school where you work. During this process, I will assign a letter to each of you and for transcribing and analysis purposes you will be known only as that letter throughout this research project.

2. Discuss how the team of counselors at your school works with all students as they go through the college admissions process.

3. Discuss how the team of counselors at your school understands the term "undocumented students."

4. Discuss how the team of counselors at your school works with undocumented students as they go through the college admissions process.

5. Discuss what you know about federal law and how it pertains to undocumented students as they go through the college admissions process.

6. Discuss your knowledge, expertise, and comfort level working with undocumented students as they go through the college admissions process.

7. Discuss what knowledge you feel you lack as a high school guidance counselor in order to best serve undocumented students as the go through the college admissions process.

8. Is there anything else related to the topic of undocumented students and their gaining access to post-secondary educational opportunities you would like to discuss? 


\section{APPENDIX C}

List of Documents Analyzed

Extreme Test Day and College Admission Testing (Power Point Presentation Oak Park High School)

The College Planning Process (Power Point presentation from Oak Park High School)

NKCSD Diploma Checklist

North Kansas City High School Profile

North Kansas City Schools BoardDocs (http://www.nkcschools.org/page.cfm?p=2317)

North Kansas City Schools Student Enrollment Form

North Kansas City Schools Program of Studies for Courses and Career Paths 2014-2015

Oak Park High School Profile

Senior College Planning Night (Power Point Presentation North Kansas City High School)

Staley High School Profile

Winnetonka High School Profile 


\section{VITA}

Martha DeVries is currently serves as a high school guidance counselor for students in the International Baccalaureate Diploma Program and International Baccalaureate Career-related Program at North Kansas City High School in North Kansas City, Missouri. She is also a workshop leader for International Baccalaureate North America. She is hoping to turn her research concerning college access for undocumented students into professional development opportunities for other high school guidance counselors. She is also interested in other areas of social justice and seems to be involved in the underdog's fight quite often.

Previously, Martha taught high school and middle school English Language Arts in Vero Beach, Florida, and English Language Learners in North Kansas City, Missouri. The move from Florida to Kansas City is often questioned, especially on days when the high temperature is nearing zero.

Martha is the wife of Mike DeVries and mother of Hannah DeVries and Haley DeVries. She is currently assisting Hannah develop and sponsor a 5K run to benefit Parkinson's Disease research, and working with Haley to develop a school-wide plan to eliminate food waste by redistributing unwanted food. Both projects are proving more difficult than anticipated. She is also an aspiring runner and banjo player. She is not really all that good at either one, but it's an interesting combination of hobbies that certainly makes for good conversation. 